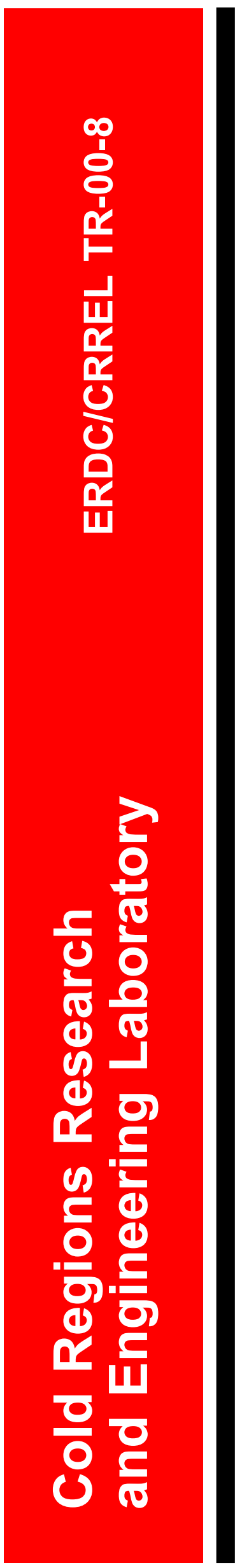

\title{
Expedient MESL Construction in Cold Weather
}

Jeffrey A. Stark, Rosa T. Affleck, and Sherri A. Orchino

July 2000

US Army Corps of Engineers ${ }_{\circledast}$

Engineer Research and Development Center 
Abstract: A new method of constructing membrane-encapsulated soil layers (MESLs) using plastic membranes, geotextiles, tapes for sealing the membranes, and absorbents for drying the soil was demonstrated. These materials would allow construction of a MESL in cold weather. The demonstration took place at Fort Drum, New York, and at Ethan Allen Firing Range, Jericho, Vermont. Three layers of a $271-\mathrm{g} / \mathrm{m}^{2}\left(8-\mathrm{oz} / \mathrm{yd}^{2}\right)$ geotextile successfully protected the membrane during a puncture test, and absorbents successfully caused the soil to act drier to increase vehicle trafficability. However, the geotextile is still too weak to be used in a MESL. Although the individual components performed well, the construction process is too exacting to be performed successfully and is not recommended for Army engineers.

How to get copies of CRREL technical publications:

Department of Defense personnel and contractors may order reports through the Defense Technical Information Center:

DTIC-BR SUITE 0944
8725 JOHN J KINGMAN RD
$\begin{array}{ll}\text { FT BELVOIR VA 22060-6218 } \\ \text { Telephone } & \text { (800) 225-3842 } \\ \text { E-mail } & \text { help@dtic.mil } \\ & \text { msorders@dtic.mil } \\ \text { wWW } & \text { http://www.dtic.mil/ }\end{array}$

All others may order reports through the National Technical Information Service:

NTIS

5285 PORT ROYAL RD

SPRINGFIELD VA 22161

Telephone (703) 487-4650

(703) 487-4639 (TDD for the hearing-impaired)

E-mail orders@ntis.fedworld.gov

WWW http://www.ntis.gov/index.html

A complete list of all CRREL technical publications is available from USACRREL (CEERD-IM-HL)

72 LYME RD

HANOVER NH 03755-1290

Telephone (603) 646-4338

E-mail_erhoff@crrel.usace.army.mil

For information on all aspects of the Cold Regions Research and Engineering Laboratory, visit our World Wide Web site:

http://www.crrel.usace.army.mil 
Technical Report

ERDC/CRREL TR-00-8

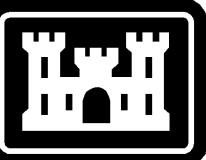

US Army Corps

of Engineers $\odot$

Cold Regions Research \& Engineering Laboratory

\section{Expedient MESL Construction in Cold Weather}

Jeffrey A. Stark, Rosa T. Affleck, and Sherri A. Orchino

July 2000 


\section{PREFACE}

This report was prepared by Jeffrey A. Stark and Rosa T. Affleck, Research Civil Engineers, and by Sherri A. Orchino, Civil Engineering Technician, Civil Engineering Research Division, U.S. Army Cold Regions Research and Engineering Laboratory (CRREL), Engineer Research and Development Center, Hanover, New Hampshire. This work was funded by DA Project 4A762784AT42, Winter Combat Engineering, Task CS, Work Unit C13, Stabilization of Thawing Soils.

Many people worked on this project. The authors thank those at Fort Drum who provided a range road, and also thank Cait Schadock, Jim Smith, and Sergeant Galey and the Fort Drum Fire Department. The project would not have been possible without their help. Others at Fort Drum also provided assistance, including Gary Burrow, Dave Hoyt, and members of Range Control. Bob Demars and Tom Knight of CRREL provided outstanding assistance during the demonstration at Fort Drum. Others from CRREL who provided support were Karen Henry, Bob Eaton, Tom Ladd, Sue Macedo, Vicki Green, and Chris Martinson.

The 365th Combat Heavy Engineering Battalion provided construction support at Fort Drum. The 131st Combat Support Equipment Company provided excellent support for the absorbent test at Ethan Allen Firing Range, Jericho, Vermont, and was a pleasure to work with.

This publication reflects the personal views of the author and does not suggest or reflect the policy, practices, programs, or doctrine of the U.S. Army or Government of the United States. The contents of this report are not to be used for advertising or promotional purposes. Citation of brand names does not constitute an official endorsement or approval of the use of such commercial products. 


\section{CONTENTS}

Preface

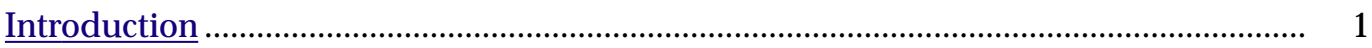

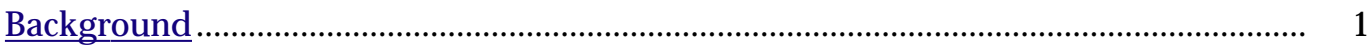

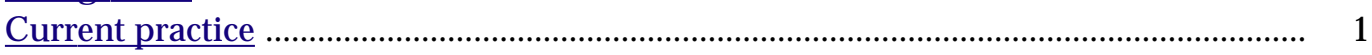

Current materials .................................................................................................. 2

Current problems in cold regions ............................................................................ 3

Proposed new method for MESL construction …………................................................ 3

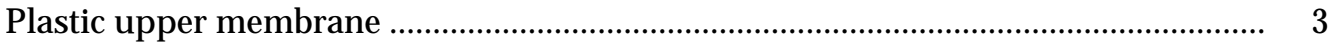

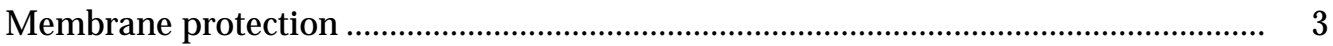

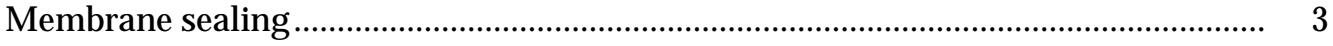

Polyethylene lower membrane ……....................................................................... 4

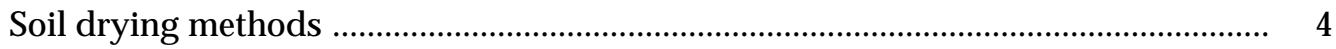

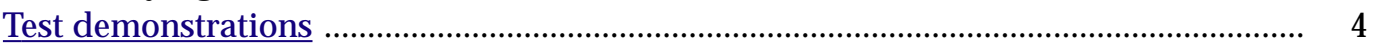

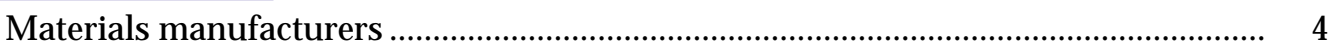

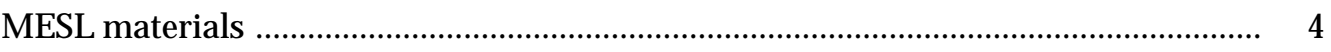

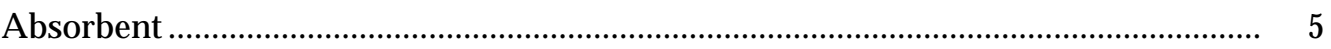

MESL demonstration ................................................................................................... 5

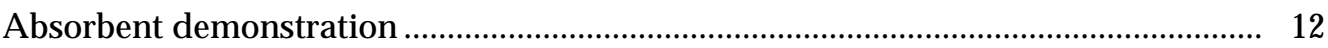

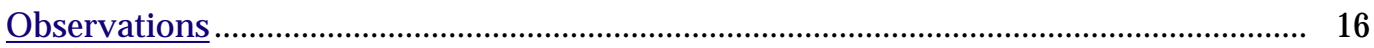

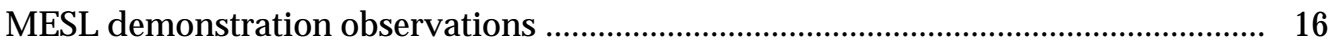

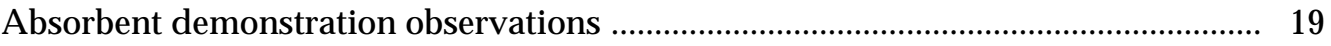

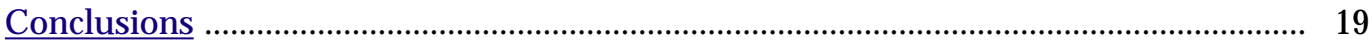

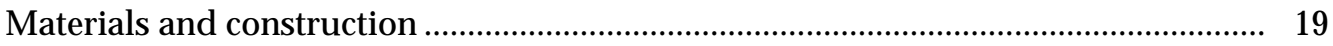

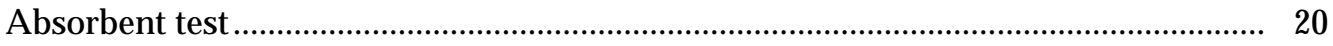

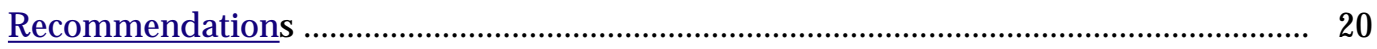

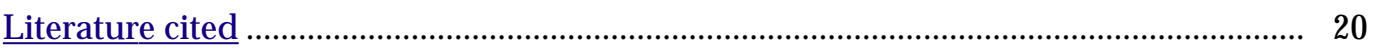

Appendix A: Recommended materials for constructing a MESL ................................... 23

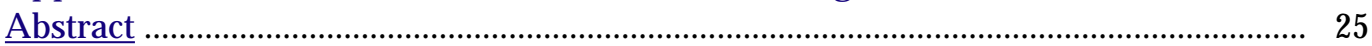

\section{ILLUSTRATIONS}

Figure

1. Cross sections of typical MESLs .............................................................................. 2

2. Test-site locations at Fort Drum, New York ……................................................... 6

3. Construction details of the MESLs ……………….............................................. 6

4. Placing fill soil inside the MESL ………......................................................... 7

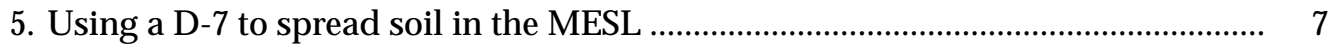

6. Taping the lower membrane .................................................................................. 8

7. Spreading the gravel wearing course on the MESL ………................................... 8 


\section{Figure}

8. Bucket loader spreading lime ........................................................................... 9

9. Grader mixing soil and lime ............................................................................... 9

10. Compacted clay layer used to simulate the top of a MESL .................................... 10

11. Completed puncture test section before placing a wearing surface ....................... 10

12. Pan placing gravel on the test section ……............................................................ 11

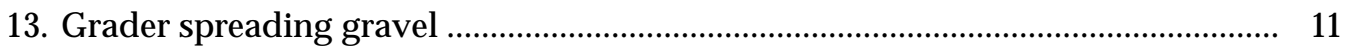

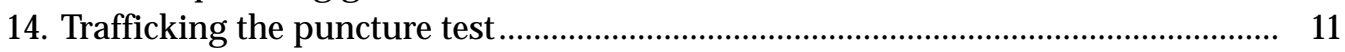

15. Equipment used to wash gravel off the test section ........................................... 12

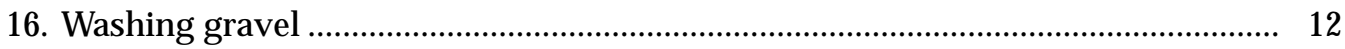

17. Adding water to the absorbent test section at Ethan Allen Firing Range,

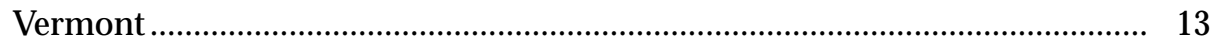

18. Trafficking the absorbent test section ................................................................. 13

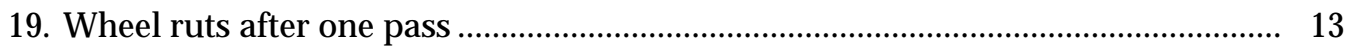

20. Absorbent spread on test section .................................................................... 14

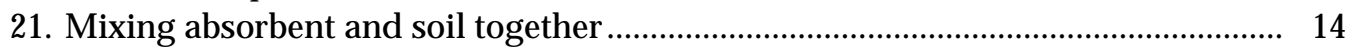

22. Test section after one pass with a CUCV ........................................................ 14

23. Trafficking the section with a 5-ton dump truck .................................................. 15

24. Test section after one pass with a 5-ton dump truck ............................................... 15

25. Test section after 30 passes with a 5-ton dump truck ............................................ 16

26. Placing top membrane during light winds ......................................................... 17

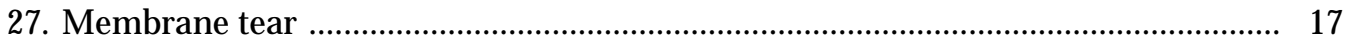

28. Top-membrane tear, caused by a bucket loader ................................................... 18

\section{TABLE}

Table

1. Number of layers of geotextile protection for puncture test ................................. 10 


\title{
Expedient MESL Construction in Cold Weather
}

\author{
JEFFREY A. STARK, ROSA T. AFFLECK, AND SHERRI A. ORCHINO
}

\section{INTRODUCTION}

The purpose of this report is to document the results of a field demonstration project using Army engineers to construct membrane-encapsulated soil layers (MESLs). The project took place in June 1997 at Fort Drum, New York, and was constructed by the 365th Combat Heavy Engineering Battalion from Pennsylvania.

Road construction typically requires substantial amounts of gravel for the base course and the wearing surface. Sometimes gravel is in short supply and alternative road building materials and practices are required. One possible alternative is to use MESLs, which make it possible to replace high-quality materials, such as gravel, with marginal-quality local materials.

If silts and clays are compacted at or below optimum moisture content, they can be very strong, even strong enough to use as base or subbase materials. This strength, however, is lost as they gain moisture. MESLs use waterproof membranes to encapsulate the silt and clays to prevent moisture gain and the subsequent loss of strength, thus allowing these materials to be used in place of gravel.

Army engineers can use the MESL concept for expedient construction of Main Supply Routes (MSRs) and other roads in the theater of operations. MESLs could be used when gravel is in short supply or the haul distances are great, and could be used to repair or construct short sections of MSRs, to cross low areas, as approaches to bridges, etc.

\section{BACKGROUND}

The MESL consists of six components: the lower membrane, the upper membrane, membrane sealing materials, the membrane protection, the fill soil, and the wearing surface (Fig. 1). At times the membrane protection and wearing surface are combined. The MESL can be constructed with the side membranes exposed, or more commonly (and preferably), with them protected. The MESL in Figure 1a is most expedient to construct and requires borrow soil. However, its membranes are more susceptible to damage and have a service life of just a few years or less. The MESL in Figure $1 \mathrm{~b}$ can use borrow soil or soil from the site on which it is placed; it is more time-consuming to construct, but its membranes are protected from damage and it has a potential service life of 20 years.

\section{CURRENT PRACTICE}

Several MESLs have been constructed by the Waterways Experiment Station (WES) and the Cold Regions Research and Engineering Laboratory (CRREL) (Joseph and Webster 1971; Joseph et al. 1973; Sale et al. 1973; Schaefer 1973; Smith and Karalius 1973; Webster 1974a, b; Webster and Andress 1976; Smith 1978, 1979; Eaton and Berg 1980). These MESLs all followed the same general design procedure; the main differences are found in the membrane protection and wearing surface. Gravel was used as a wearing surface on some of them and asphalt concrete on others. The materials used for the various components are listed below. 

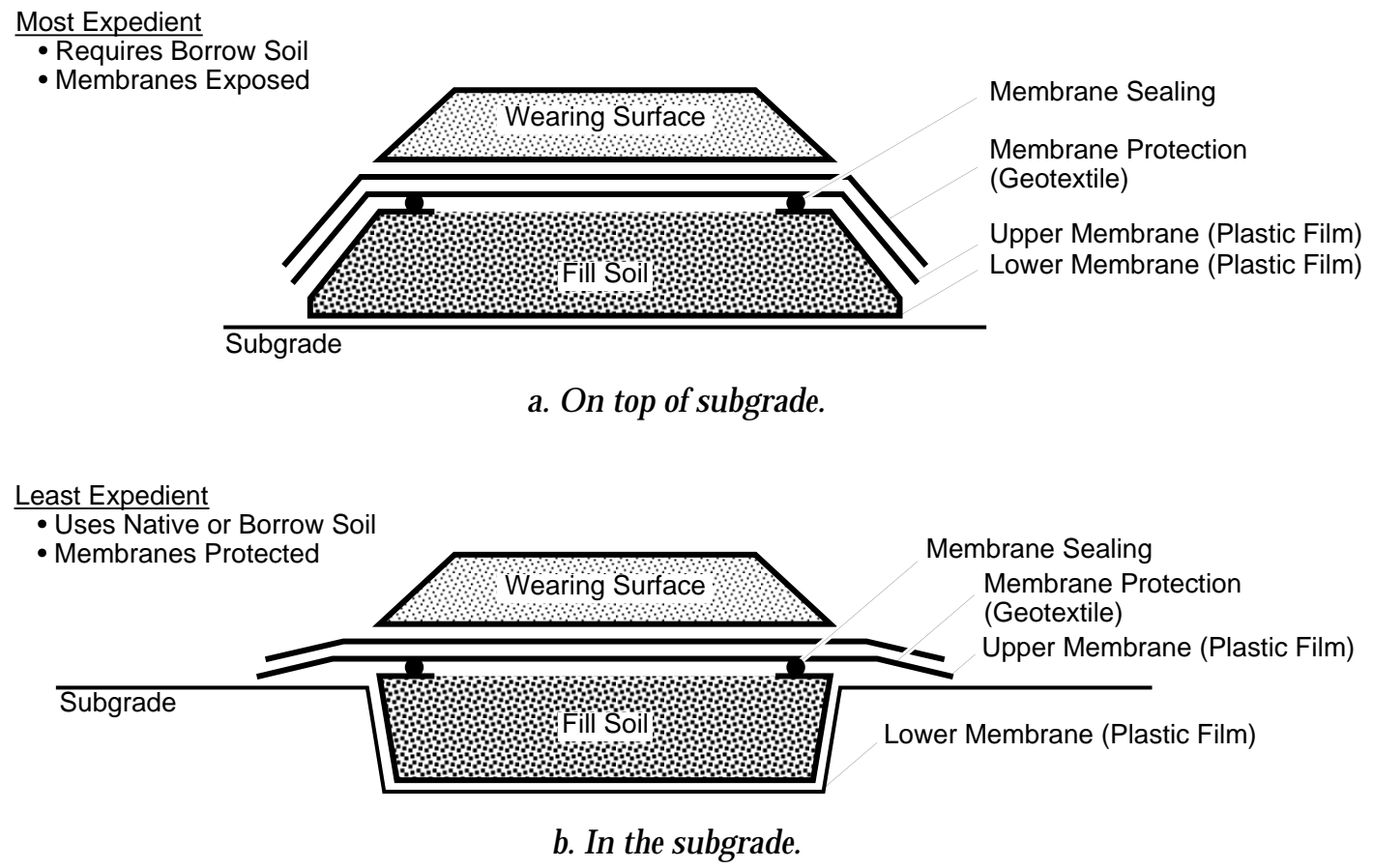

Figure 1. Cross sections of typical MESLs.

\section{Current materials}

The following information is primarily from Implementation Package 74-2, Users Manual for Membrane Encapsulated Pavement Sections (MEPS), by S.L. Webster (1974b).

\section{Lower membrane}

The lower membrane is formed by first spraying emulsified asphalt on the soil at a rate of 0.9 to $1.4 \mathrm{~L} / \mathrm{m}^{2}\left(0.2\right.$ to $\left.0.3 \mathrm{gal} / \mathrm{yd}^{2}\right)$ on the subgrade. This holds the plastic membrane in place and can seal small punctures that occur in the plastic membrane, which is typically $0.152-\mathrm{mm}-(6-\mathrm{mil})$ thick polyethylene, 9.1 to $12.2 \mathrm{~m}$ (30 to $40 \mathrm{ft}$ ) wide and $30.5 \mathrm{~m}(100 \mathrm{ft})$ long. The membranes are joined together by overlapping the sheets by two to three feet and spraying emulsified asphalt between them.

\section{Upper membrane}

The surface of the finished soil layer is first sprayed with a small amount of water to dampen it, and is then sprayed with 1.1 to $2.3 \mathrm{~L} / \mathrm{m}^{2}(0.25$ to $\left.0.5 \mathrm{gal} / \mathrm{yd}^{2}\right)$ of emulsified asphalt. A needlepunched nonwoven polypropylene fabric (such as Petromat) is unrolled on top of the emulsified asphalt. The fabric is then sprayed with 0.9 to 1.4 $\mathrm{L} / \mathrm{m}^{2}\left(0.2\right.$ to $\left.0.3 \mathrm{gal} / \mathrm{yd}^{2}\right)$ of emulsified asphalt. A thin layer of blotter sand (dry sand passing the number 4 sieve) is spread on top of the emulsified asphalt using a chip spreader to prevent tires from picking up the asphalt.

\section{Membrane sealing materials}

Emulsified asphalt is used to seal all the membranes. At least a $0.3-\mathrm{m}(1-\mathrm{ft})$ overlay should be used at all seams.

\section{Membrane protection and wearing surface}

Protection is not required if only wheeled vehicles are going to use the newly constructed road. It will last for approximately 10,000 passes with very little maintenance (Webster and Andress 1976, Webster 1996), but vehicles cannot make sharp turns or sudden starts and stops. If a gravel wearing surface is going to be used, $51 \mathrm{~mm}$ ( 2 in.) of "cushion" sand is used between the membrane and the gravel to prevent puncturing of the membrane (Smith 1979). An asphaltic concrete pavement wearing course will also provide the needed membrane protection (Webster and Andress 1976).

\section{Encapsulated soil}

The encapsulated soil is typically one that loses considerable strength when it gets wet, such as a clay or silt. The soil needs to be placed at moisture content near its optimum or lower in warm climates. In cold climates, where freezing of the soil will occur, the soil should be placed so it is no 
more than 70\% saturated (Smith 1979). At higher saturation levels, the moisture within the MESL can migrate to the top during freezing and cause localized thaw weakening.

If encapsulated soils are too wet to be placed directly in the MESL, the soil is dried or modified by one of several methods: air drying, adding drier material to it, or using chemicals to dry or modify the soil.

Wet soil is commonly air-dried. This method is very weather-dependent and time-consuming. Lime (quick or hydrated) is an excellent drying chemical for clay and clayey soils. Lime modifies the soil and can act as a stabilizing agent if used in sufficient quantity. However, it is relatively ineffective on silts and silty sands. Fly ash effectively modifies clayey soils and dries soils because it is typically dry when added.

\section{Current problems in cold regions}

Emulsified asphalt

Emulsified asphalt is used to form the top membrane, as part of the lower membrane, and for sealing the membranes. It is best used when the air and surface temperature is above $10^{\circ} \mathrm{C}\left(50^{\circ} \mathrm{F}\right)$ (Asphalt Institute undated). Thus, for cold regions, the construction season could be limited. The liquid emulsified asphalt also needs to be kept from freezing because freezing will prematurely break the emulsion (Asphalt Institute undated). A potential problem is that military Combat Support Equipment (CSE) companies do not have the asphalt distributors required to spray the asphalt.

\section{Membrane damage}

The current membrane allows only wheeled vehicles to travel on it. If a gravel wearing surface must carry tracked-vehicle traffic, a cushion layer of clean sand is necessary. Clean sand will not have sharp, larger particles that could puncture the membrane, and will retain its strength when wet. This requires a clean sand source. The problem is compounded by the difficulty of placing a 51-mm(2-in.-) thick sand layer without damaging the membrane.

\section{Drying encapsulated soil}

Borrow soil used for a MESL commonly has an above-optimum water content. Lime is commonly used to dry soil and is very effective in clayey soils; however, it has little effect in other soils. Therefore, a quick method to dry soils such as dirty sands is required.

\section{PROPOSED NEW METHOD FOR MESL CONSTRUCTION}

A proposed new method for MESL construction would eliminate the use of emulsified asphalt and use plastic membranes and tapes instead. This would allow construction at all temperatures and would eliminate the need for an asphalt distributor. The membranes are not affected by temperature and are easily transported and stored.

\section{Plastic upper membrane}

The emulsified asphalt will be replaced with a plastic membrane. Polyethylene plastic membranes are flexible at $0^{\circ} \mathrm{C}\left(32^{\circ} \mathrm{F}\right)$ and below (Raven Industries undated $b-d$ ). They also require a minimal amount of special equipment to install. The selection of the upper membrane is critical to the success of the MESL. There must be a balance between cost, performance, and ease of installation. It is estimated that a $0.31-\mathrm{mm}$ - (12-mil-) thick membrane could be used for short design lives (up to one year) and a $0.51-\mathrm{mm}(20-\mathrm{mil})$ membrane for longer design lives (one to five years). As the membrane gets thicker, however, it becomes more difficult to handle and to lay flat.

\section{Membrane protection}

The upper membrane must be protected from traffic. It is likely that a CSE company would use gravel as a wearing surface in a theater of operations. For a gravel wearing surface, the amount of membrane protection required will depend on the type of gravel used, thickness of the gravel layer, type and quantity of traffic, and service life.

Geotextiles are commonly used to protect membranes from puncture. They are inexpensive, easy to install, transport, and store. The total mass per unit area of the geotextile should be at least $813 \mathrm{~g} / \mathrm{m}^{2}\left(24 \mathrm{oz} / \mathrm{yd}^{2}\right)$ (Koerner et al. 1996, Narejo et al. 1996, Richardson 1996, Wilson-Fahmy and Koerner 1996), such as three layers of a 271 $\mathrm{g} / \mathrm{m}^{2}\left(8 \mathrm{oz} / \mathrm{yd}^{2}\right)$ fabric, to provide sufficient protection for most applications.

\section{Membrane sealing}

Heat and tape are the two basic methods used to seal the membranes. The heat methods, such as iron or hot air welding, generally give higherquality seams. However, they require skilled technicians to run the specialized equipment, and it is very easy to melt holes in thin membranes.

Tapes provide good seals with limited train- 
ing. A variety of tapes are available from various manufacturers. The drawback to tapes is that they are best applied when the temperature is above $10^{\circ} \mathrm{C}\left(50^{\circ} \mathrm{F}\right)$. This can be overcome in a variety of ways. The tapes can be kept warm in a heated vehicle and applied quickly before they cool, or they could be heated with a heat gun or electric hair drier. (This would require using a small generator.)

\section{Polyethylene lower membrane}

The lower membrane will be $0.152-$ to $0.23-\mathrm{mm}$ (6- to 9-mil) polyethylene membrane. Tapes will be used for the seams. The membranes can be purchased in long lengths (152 m [167 yd]) to minimize seams. It is important to purchase quality membranes from reputable manufacturers. Low-quality membranes can contain defects and additives that can reduce their life.

\section{Soil drying methods}

Various methods can be used to dry the soils. Chemical methods can be done quickly and, if properly done, are well suited for Army engineers. Lime is the best chemical to use with clayey soils. A method to dry silty sands needs to be developed.

A potential method to make silty sands act drier involves the use of commercially available superabsorbent polymers. The polymers don't actually dry the soil; they concentrate the water in the absorbent and dry the surrounding soil matrix. They have potential benefits and drawbacks. The benefits are that (1) only a small amount (between .15 and .5 percent) of absorbent is needed, (2) they are relatively safe to handle, (3) they have a minimal impact on the environment, (4) they are very fast acting, and (5) they are unaffected by the cold.

A drawback is that the swelled absorbent is spongy, thereby making the soil spongy. The wetter the soil is to begin with, the spongier the soil will be after the absorbent is added. The absorbents absorb less as confining pressure is increased. This means a truck could not park on the absorbenttreated soil because it would force the water out of the absorbent. Absorbents also degrade with time. It is possible to add too much absorbent, which would over-dry the soil and make it friable. However, even with the disadvantages, absorbents are a potential drying agent for MESLs with a short design life and a silty sand fill soil.

\section{TEST DEMONSTRATIONS}

The demonstrations were conducted at Fort Drum, New York, and at the Ethan Allen Firing Range (EAFR), Jericho, Vermont. A different engineering unit was used at each site.

\section{Materials manufacturers}

Following is a list of manufacturers and products used in the demonstrations.

- Raven Industries, Sioux Falls, South Dakota: RUFCO 610B, 1010B, 2010B, and 3010B; DURA-SKRIM 12 BBR membranes; and Poly Seal tape.

- Reef Industries, Houston, Texas: Permalon Ply X-150, Ply X-210, Ply X-210G membranes, and Fab tape.

- Webtec, Inc., Charlotte, North Carolina: TerraTex N08 geotextile.

- Stockhausen, Inc., Greensboro, North Carolina: AP 88 superabsorbent.

- Specialty Minerals Company, Adams, Massachusetts: commercial-grade quicklime.

\section{MESL materials}

The materials are separated by the project in which they were used and the function they performed.

\section{MESL test materials}

Upper membrane. Two different membranes, DURA-SKRIM 12 BBR and RUFCO 2010B, were used for the top membrane.

The DURA-SKRIM $12 \mathrm{BBR}$ is $0.31 \mathrm{~mm}$ (12 mil) thick. Its manufacturer describes it as two sheets of high-strength polyethylene film laminated together with a third layer of molten polyethylene, with a heavy polyester skrim reinforcement placed between the plies to enhance tear resistance (Raven Industries undated $b$ ). The machine width of the membrane is $1.83 \mathrm{~m}(6 \mathrm{ft})$. If widths greater than $1.83 \mathrm{~m}(6 \mathrm{ft})$ are desired, the factory can seam several sheets together. The final membrane is accordion-folded and rolled on a core.

The RUFCO 2010B is a 0.51-mm- (20-mil-) thick monolayer membrane consisting of a blend of medium-density polyethylene manufactured from virgin and selected reprocessed resins (Raven Industries undated c).

Lower membrane. The RUFCO 610B is 0.152 $\mathrm{mm}(6 \mathrm{mil})$ thick. It is a monolayer membrane consisting of a blend of high-strength, mediumdensity polyethylene manufactured from virgin and selected reprocessed resins. According to its 
manufacturer, its puncture and tear strengths far exceed common 6-mil polyethylene and vinyl films (Raven Industries undated d).

The Reef Permalon Ply X-150 is $0.23 \mathrm{~mm}$ (9 mil) thick. It is a high-density cross-laminate polyethylene that resists punctures and tears (Reef Industries 1996b).

Membrane seams. Two types of tapes were used: Poly Seal by Raven Industries, and Fab tape by Reef Industries. Both are double-sided and come in 30-m (33-yd) rolls.

Poly Seal is a transparent, 51-mm- (2-in.-) wide rubber resin tape (Raven Industries undated a) that sticks extremely well to plastic. Once the tape is on the plastic it cannot be removed without damage to itself. The tape is light and can be difficult to place in windy conditions.

Fab tape is a black, double-sided, reinforced asphaltic pressure-sensitive mastic, $38 \mathrm{~mm}$ (1.5-in.) wide (Reef Industries 1996a). It is heavier than the Poly Seal and therefore easier to place. It can be removed from the plastic for repositioning if required.

Upper membrane protection. The geotextile used was TerraTex N08, manufactured by Webtec, Inc. It is a nonwoven polypropylene fabric with a weight of $271 \mathrm{~g} / \mathrm{m}^{2}\left(8 \mathrm{oz} / \mathrm{yd}^{2}\right)$. This geotextile was chosen because it was stocked and supplied locally. Similar fabrics from other manufacturers should perform equally well. This geotextile met or exceeded the specifications in Construction with Geotextiles (Webster 1996), which includes the Geotextile Specification for General Army Engineer Use.

Wearing surface. Gravel for range road maintenance and construction from a stockpile at Fort Drum was used as the wearing surface. It was $100 \%$ crushed, dense-graded, with a 51-mm (2-in.) maximum particle size.

Encapsulated soil. The encapsulated soil was lean clay (CL) stockpiled from a previous construction project.

Treating the encapsulated soil. Lime was added to the soil as a stabilizing agent in case the MESLs were damaged during construction or planned testing. The lime was commercial-grade, granular quicklime that came in one-ton plastic supersacks.

\section{Puncture test and membrane protection materials}

Membranes. The following membrane manufacturers were used.

- Raven Industries. The membranes used can be divided into two types. The first is a singlelayer membrane with some recycled plastic.
These are the RUFCO 1010B, 2010B, and 3010B. They are $0.254,0.51$, and $0.76 \mathrm{~mm}(10$, 20 , and 30 mil) thick, respectively, and are similar to the 2010B described above.

The second type was the DURA-SKRIM 12 $\mathrm{BBR}$, which is described above.

- Reef Industries. The membranes tested were the Permalon Ply X-210 and Ply X-210G. They are identical except that the Permalon Ply X-210G has a nonwoven needle-punched geotextile bonded to it, making it a composite membrane. The Permalon Ply X-210 is a highdensity, cross-laminated polyethylene that resists punctures and tears and is $0.51 \mathrm{~mm}$ (20 mil) thick (Reef Industries 1996c). The Permalon Ply X-210G is $1 \mathrm{~mm}$ (40 mil) thick (Reef Industries 1996d).

The geotextile used was Webtec, Inc.'s TerraTex N08, described above.

\begin{abstract}
Absorbent
The absorbent used was AP 88, a sodium polyacrylate from Stockhausen, Inc. (Stockhausen 1997). It can absorb approximately 325 times its weight in free water.* When mixed with soil, it absorbs significantly less. The amount of water that it absorbs depends on the soil type and moisture content. It will absorb the most water in a dirty sand, less in a silt, and the least in a clay. AP 88 is available in $22.7-\mathrm{kg}$ (50-lb) bags.
\end{abstract}

\section{MESL demonstration}

Funding and availability of engineering troops delayed onset of the demonstration, which eventually took place at Fort Drum, New York, from 10 to 17 June 1997. The 365th Combat Heavy Engineering Battalion from Pennsylvania agreed to perform the construction as part of its annual training.

These delays meant the demonstration would take place during warm weather instead of cold. This alternative was pursued on the assumption that if the project was a success, any procedures that would be affected by the cold would be repeated in coldrooms at CRREL.

The test work took place in three locations (Fig. 2). The MESLs were constructed on Poagland Road. The puncture test was conducted at the old wash-rack site on Highway 26. Clay soil used in the MESL came from Hoyt's Hill, about 30 minutes from Poagland Road.

\footnotetext{
* Personal communication, J.E. Mills, Stockhausen, Inc.,
} Greensboro, North Carolina, 1997. 


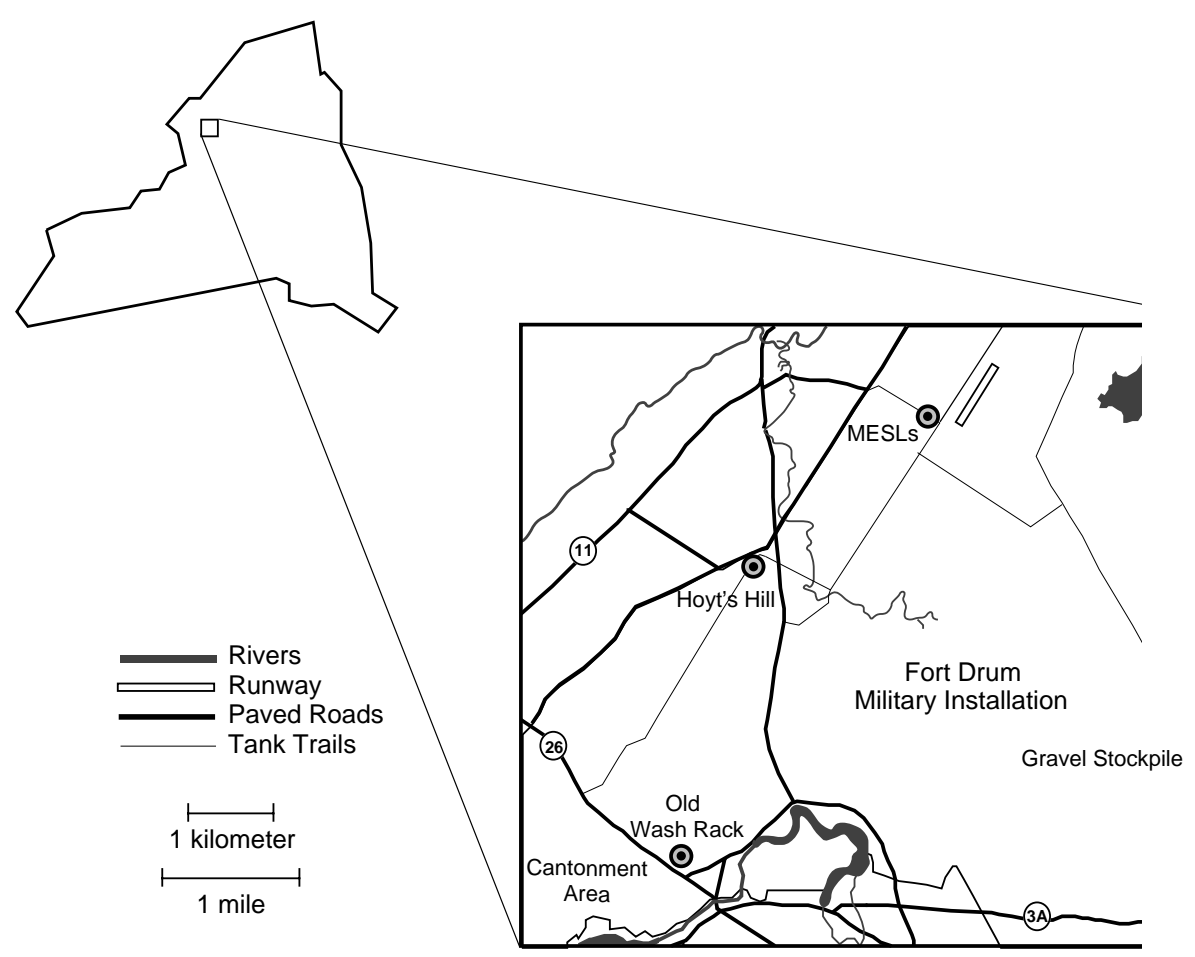

Figure 2. Test-site locations at Fort Drum, New York.

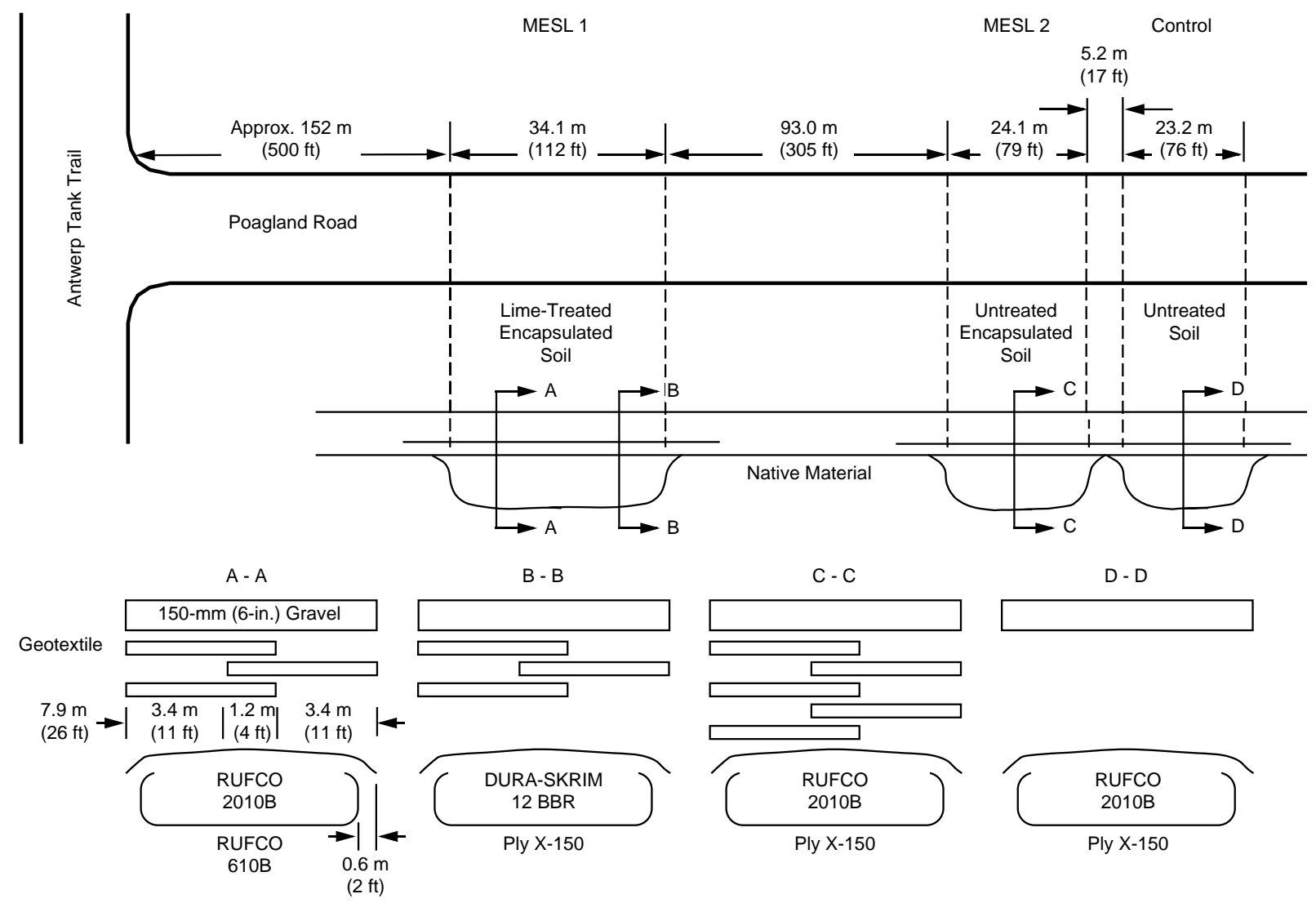

Figure 3. Construction details of the MESLs. 


\section{MESL test}

Two MESLs and a control section were constructed. MESL 1 used lime-treated clay as the encapsulated soil, and MESL 2 used untreated clay as the encapsulated soil. MESL 1 used two different membranes on top and bottom (Fig. 3). One reason for doing this was to determine whether there were any difficulties seaming two membranes together. To protect the upper membrane, one layer of geotextile was placed on one side of the road and two layers of geotextile were placed on the other side.

MESL 2 was constructed similarly to MESL 1 except the top and bottom membranes did not have a seam in the middle. The amount of geotextile protection was increased to two layers on each side and an additional layer in the middle. The control section was similar to MESL 2 except no membranes were used. The MESLs were approximately $457 \mathrm{~mm}$ (18 in.) deep and $6.7 \mathrm{~m} \mathrm{(22} \mathrm{ft)}$ wide.

\section{MESL construction}

The MESL construction was conducted at Poagland Road. A D-7 bulldozer, pans, and a 2.5- yard bucket loader were used to excavate the sections to a depth of $457 \mathrm{~mm}$ (18 in.). The material was loosened by using the ripper teeth on the D-7. The loosened material was then removed using the pans and transported for use at a different construction site.

The D-7 and the bucket loader were used to smooth the excavation. The area was then cleared of any sharp material by hand and the lower membranes were placed in the excavation. At the locations where a seam was needed, the membranes were cleaned with isopropyl alcohol and wiped dry. Tape was applied and the membranes were joined. A small hand-held roller was used to smooth the seam and ensure a watertight seal. The ends of the membrane were folded back to the edge of the excavation and covered with geotextile fabric and plywood to prevent damage from the trucks dumping the fill material.

The fill material was transported to the site in 20-ton dump trucks. Because vehicle traffic would damage the membranes, the trucks had to back to the edge of the excavation to dump the fill soil (Fig. 4) and a dozer pushed the material over the membrane (Fig. 5). A loaded 20-ton dump

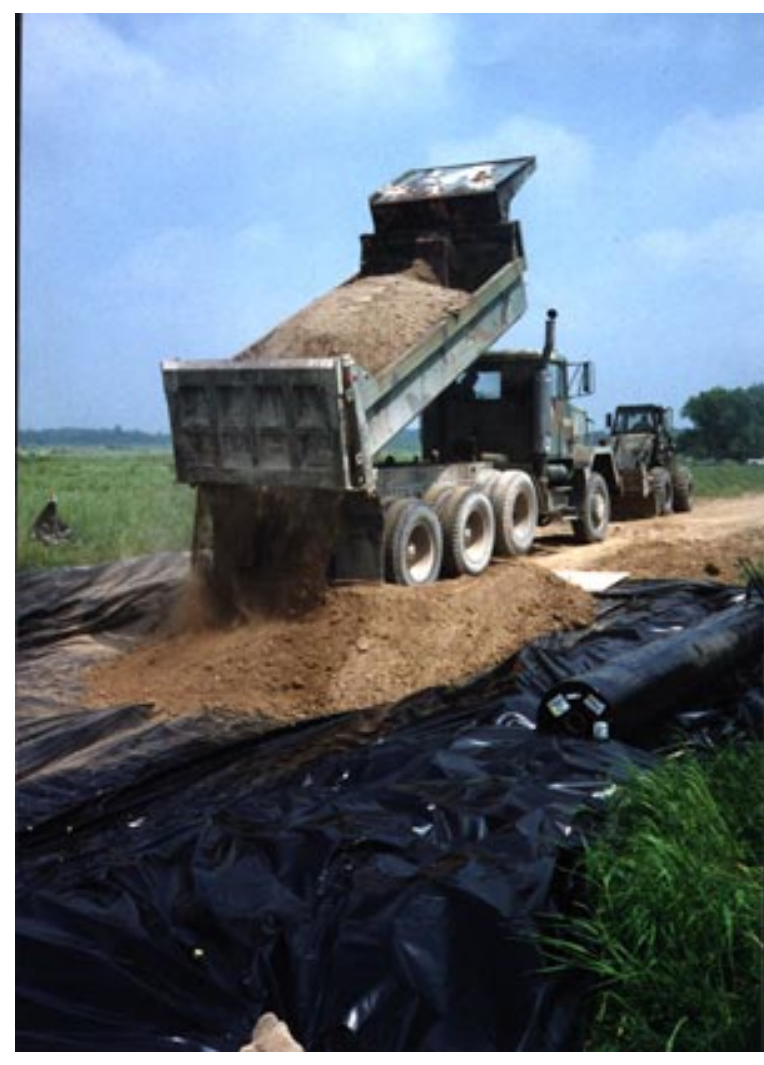

Figure 4. Placing fill soil inside the MESL.

Figure 5. Using a D-7 to spread soil in the MESL.

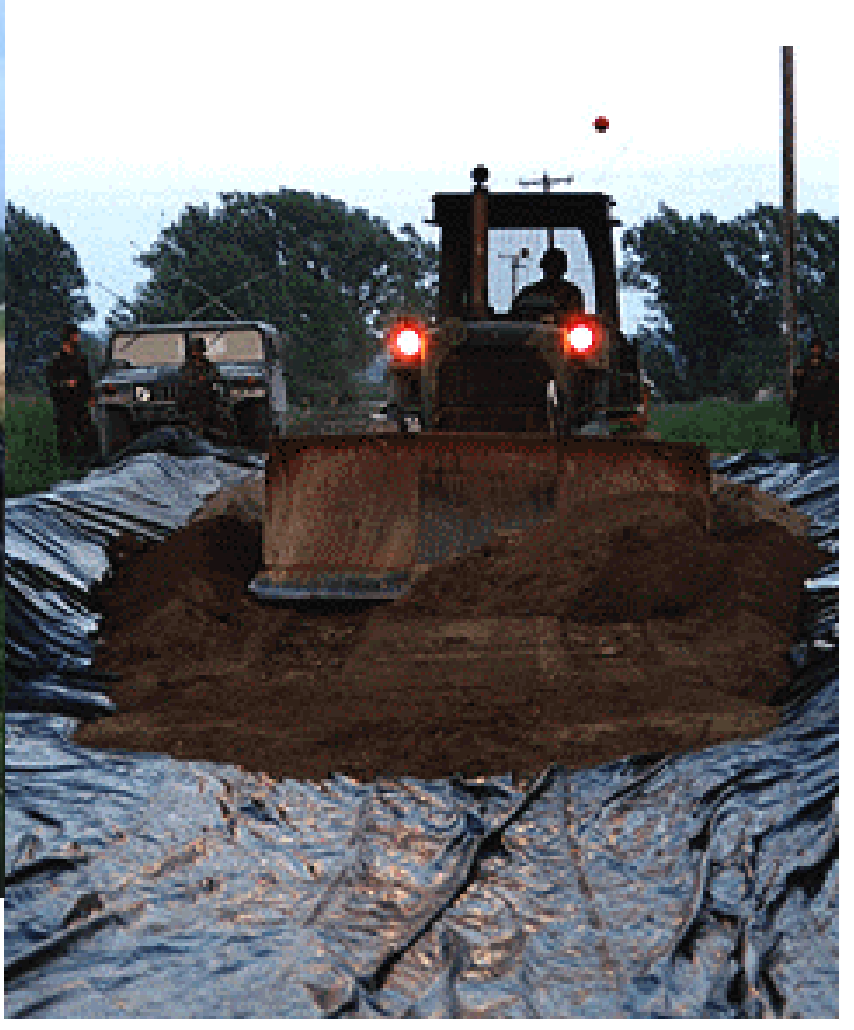




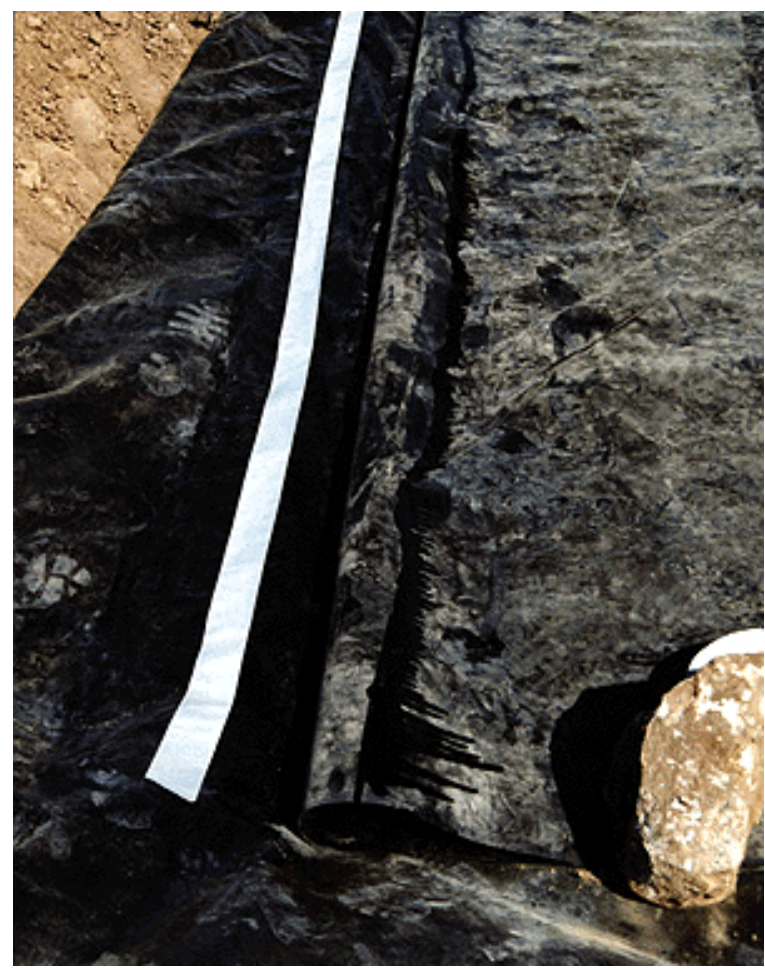

Figure 6. Taping the lower membrane; the upper membrane is being cleaned.

truck was used to compact the soil in 127-mm (6-in.) lifts. Final density and water content were not measured.

After the MESL sections were filled and compacted to $457 \mathrm{~mm}$ (18 in.), the D-7 and the bucket loader were used to smooth the surface. The surface was crowned to allow water to run off the road surface. Sharp rocks and objects were removed from the surface of the encapsulated soil.

The ends of the lower membrane were uncovered and unfolded. The sides of the lower membrane were folded over the top of the fill soil. The top membrane was laid in place on the MESL. The areas to be sealed were cleaned with isopropyl alcohol, dried, and taped (Fig. 6).

A geotextile was placed on top of the membrane for protection from the gravel layer. The geotextile extended $3 \mathrm{~m}(10 \mathrm{ft})$ beyond the ends of the MESL and extended $0.61 \mathrm{~m}(2 \mathrm{ft})$ beyond the sides of the MESL. The geotextiles overlapped each other approximately $1.2 \mathrm{~m}(4 \mathrm{ft})$ along the centerline of the MESL.

The gravel for the wearing surface was brought to the site in 20-ton dump trucks. Once again the trucks had to back to the edge of the MESL to dump the gravel to avoid damaging the membrane. The D-7 dozer and a bucket loader were used to spread the gravel over the MESL. On the final day of construction a grader was brought from another construction site to spread the gravel to a 152-mm (6-in.) lift (Fig. 7). The gravel was compacted by vehicle traffic.

\section{Soil-lime mixing}

The soil and lime were mixed at Hoyt's Hill and delivered to the MESL site. The soil is a lean clay that was stockpiled from a wetlands remediation project. The mixing area was approximately $30 \mathrm{~m}$ by $30 \mathrm{~m}(100 \mathrm{ft}$ by $100 \mathrm{ft})$ and the site was approximately $61 \mathrm{~m}$ by $61 \mathrm{~m}(200 \mathrm{ft}$ by $200 \mathrm{ft})$.

The mix area was graded smooth to eliminate

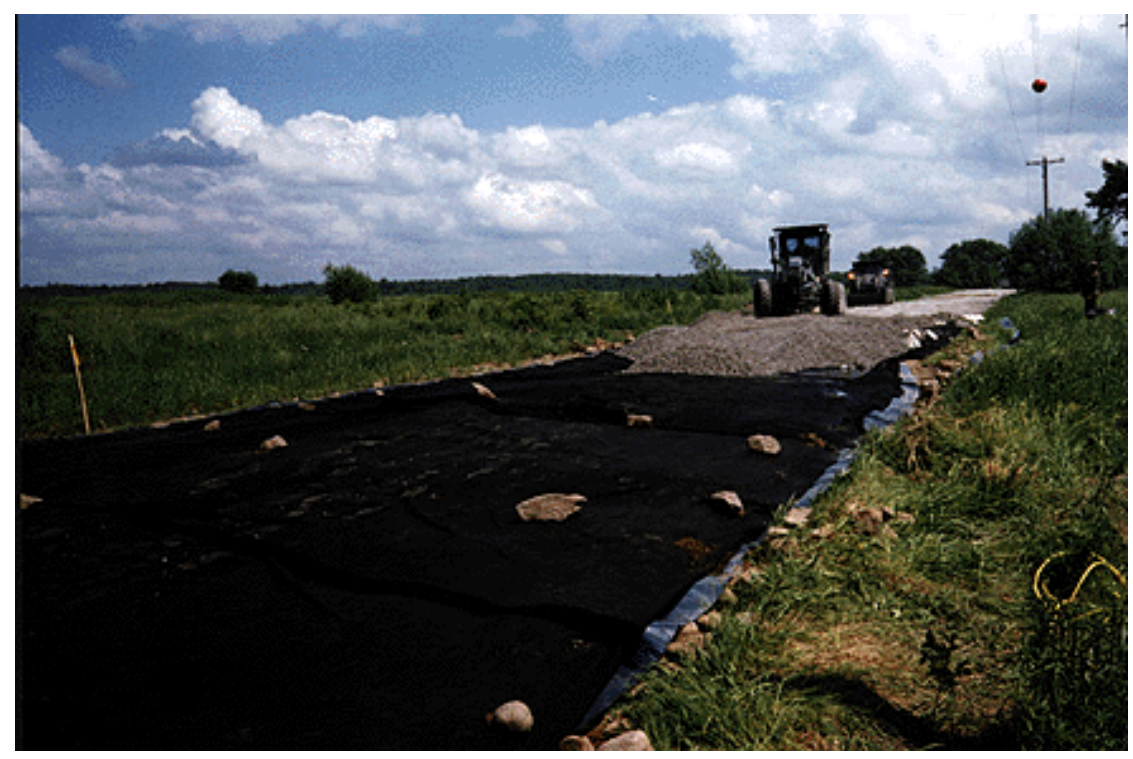

Figure 7. Spreading the gravel wearing course on the MESL. 
small gullies formed by erosion. The one-ton supersacks of lime were loaded on a lowboy trailer using a forklift and were then delivered to the site where a bucket loader was used for unloading. The supersacks were picked up with the loader using four chains placed through loops on the bag. The bucket loader carried the bags to the mixing area where three holes were cut in the bottom of the bags. The loader then drove back and forth to spread the lime (Fig. 8) in lines with piles of lime where the bags were opened and where the loader changed directions. Water was then spread on the lime to hydrate it and wet the clay. The clay was dry because the soil was sloped and exposed to the sun.

The scarifying teeth of a grader were used to mix lime into the soil to a depth of approximately $102 \mathrm{~mm}$ (4 in.) (Fig. 9); the soil also was bladed. Water was added several times until there was enough moisture for compaction.

A bucket loader was used to stockpile the 102mm- (4-in.-) thick soil-lime mixture for loading into dump trucks. At times, the thickness of the soil removed was more than or less than $102 \mathrm{~mm}$ (4 in.). The stockpiling and loading assisted a great deal in mixing the soil and lime. The final lime content, water content, and the mix consistency were not measured.

\section{Puncture test}

A puncture test was conducted to determine the amount of protection required for various membranes. The membranes must be able to survive construction and trafficking with no punc-

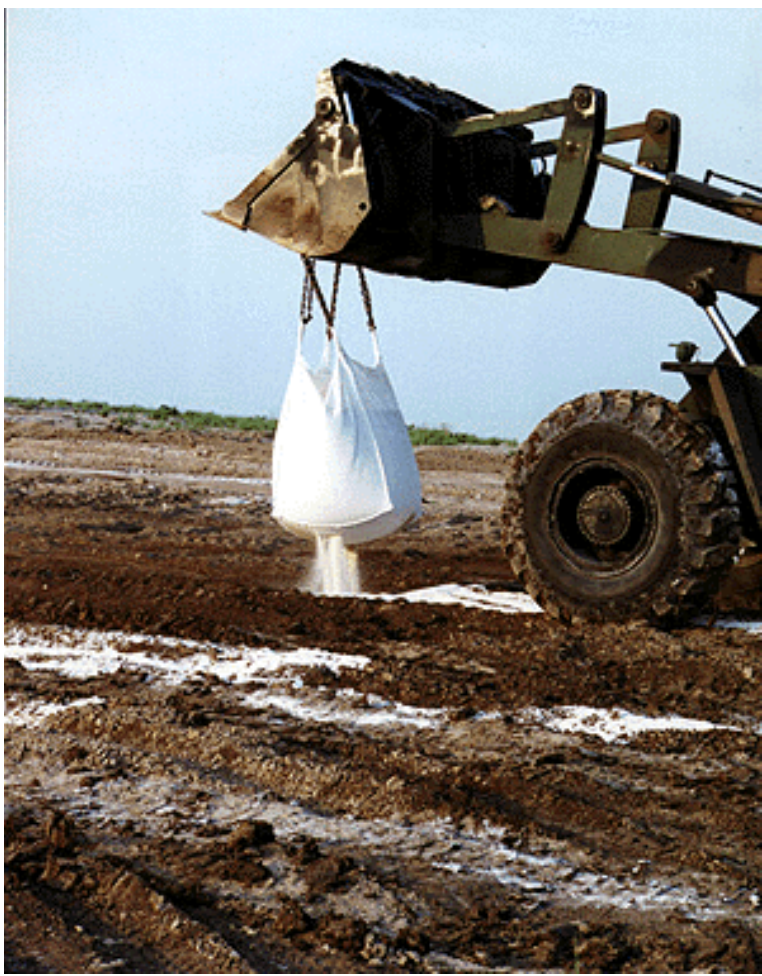

Figure 8. Bucket loader spreading lime.

tures. Even one or two punctures could allow enough water to reach the encapsulated soil and cause failure of the MESL.

The puncture test was conducted behind the old wash rack on Highway 26. The test section was $4.6 \mathrm{~m}(15 \mathrm{ft})$ wide and $30 \mathrm{~m}(100 \mathrm{ft})$ long. On both sides of the test section, a trench $250 \mathrm{~mm}$ $(1 \mathrm{ft})$ deep and $2.4 \mathrm{~m}(8 \mathrm{ft})$ wide was dug using the

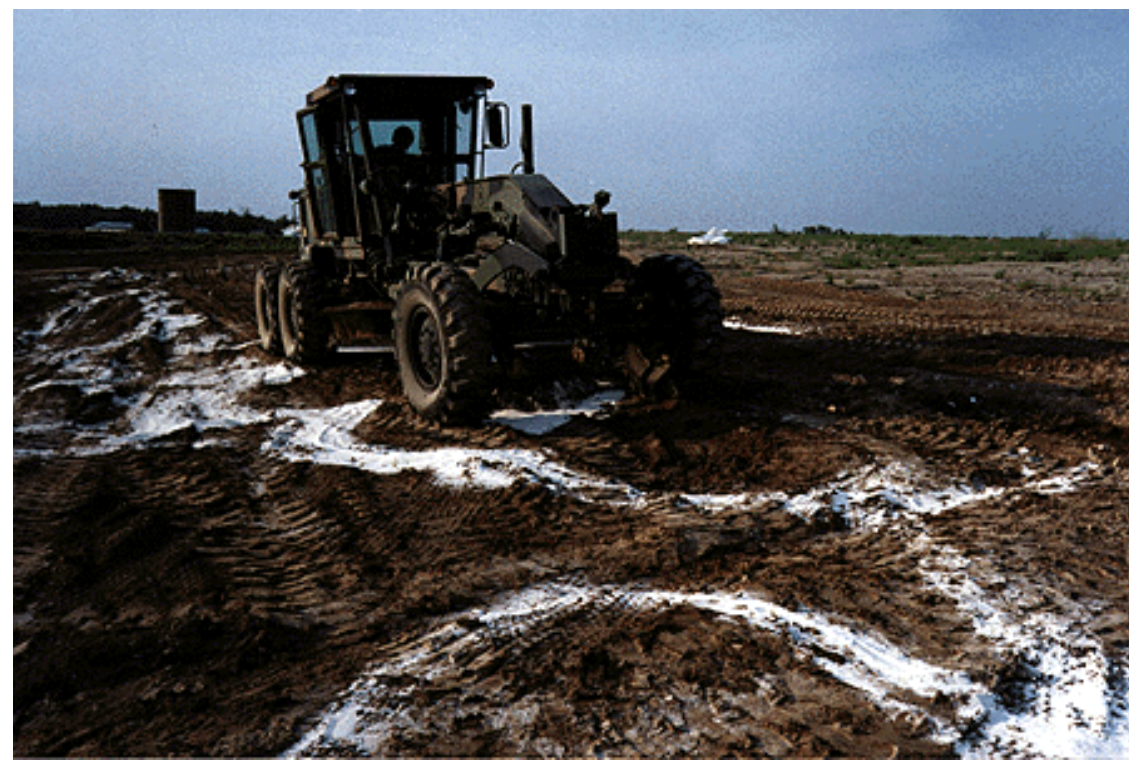

Figure 9. Grader mixing soil and lime. 


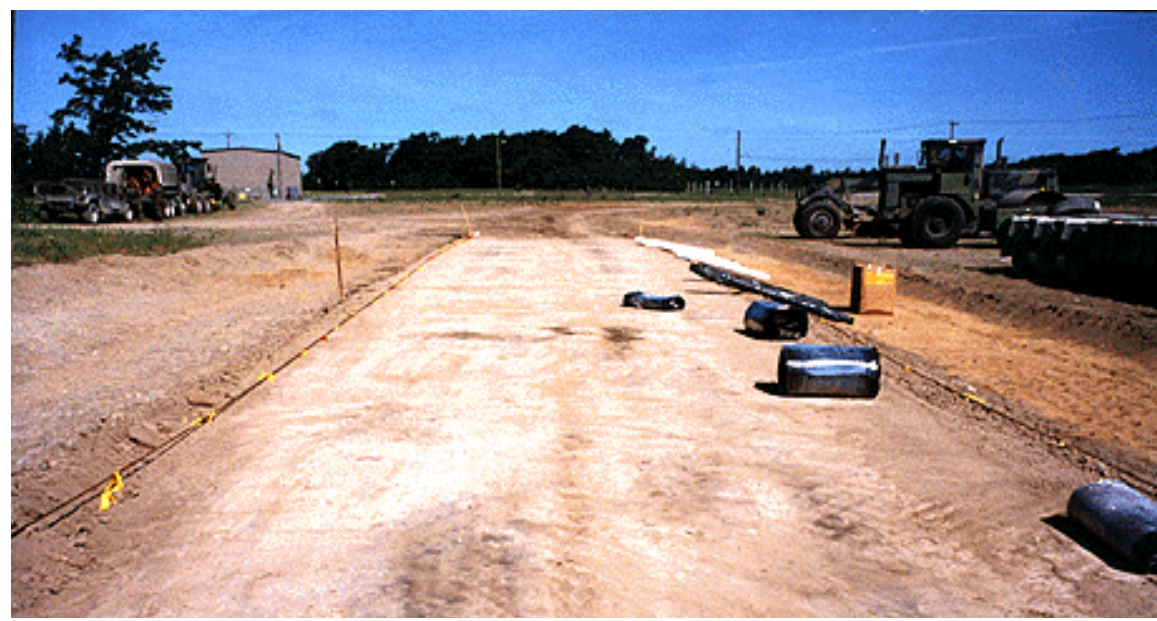

Figure 10. Compacted clay layer used to simulate the top of a MESL.

Table 1. Number of layers of geotextile protection for puncture test.

\begin{tabular}{|c|c|c|c|c|c|c|c|c|c|c|c|}
\hline & \multicolumn{11}{|c|}{ Membrane Manufacturers } \\
\hline & \multicolumn{7}{|c|}{ Raven } & \multicolumn{4}{|c|}{ Reef } \\
\hline & $\begin{array}{c}\text { RUFCO } \\
2010\end{array}$ & $\begin{array}{c}\text { RUFCO } \\
2010\end{array}$ & $\begin{array}{c}\text { RUFCO } \\
3010\end{array}$ & $\begin{array}{c}\text { RUFCO } \\
1010\end{array}$ & $\begin{array}{c}\text { RUFCO } \\
2010\end{array}$ & $\begin{array}{l}\text { DURA- } \\
\text { SKRIM }\end{array}$ & $\begin{array}{l}\text { DURA- } \\
\text { SKRIM }\end{array}$ & $\begin{array}{c}\text { PLYX- } \\
210\end{array}$ & $\begin{array}{c}\text { Ply X- } \\
210 G\end{array}$ & $\begin{array}{c}\text { Ply X- } \\
210 G\end{array}$ & $\begin{array}{c}\text { Ply X- } \\
210\end{array}$ \\
\hline Left wheel & 0 & 2 & 2 & 2 & 3 & 3 & 2 & 2 & 2 & 0 & 0 \\
\hline Right wheel & 0 & 1 & 1 & 1 & 2 & 2 & 1 & 1 & 1 & 0 & 0 \\
\hline
\end{tabular}

Figure 11. Completed puncture test section before placing a wearing surface.

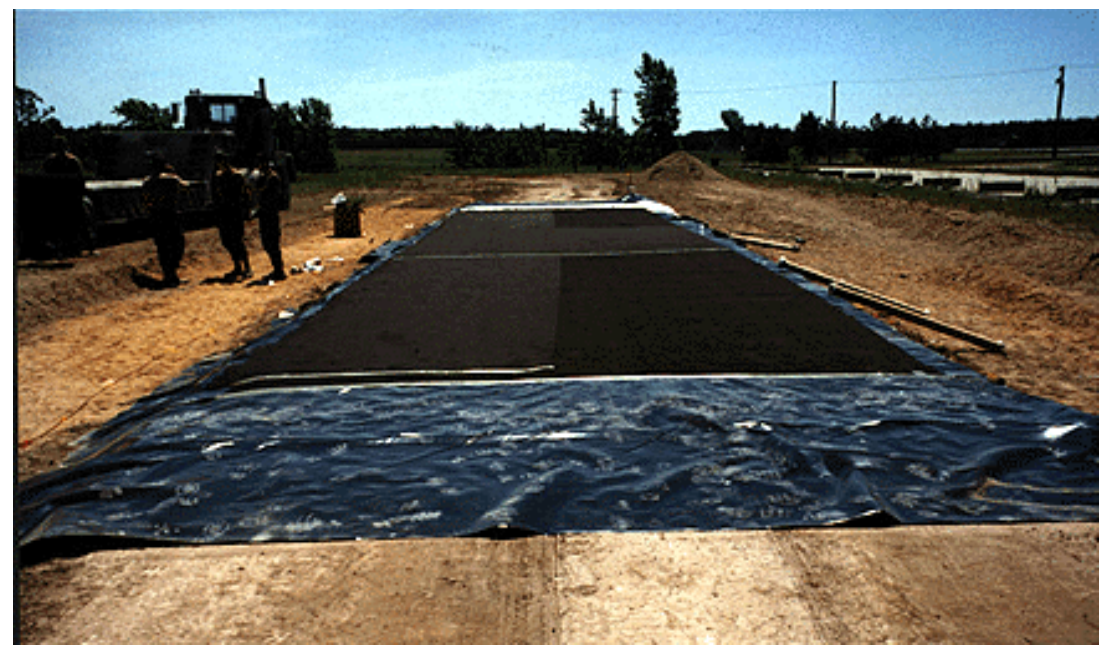

pan. These trenches provided an area to wash the gravel into when the test was completed. Next, six inches of clay was placed on the test section. Water was added to the clay, scarified, and compacted to simulate the top of a finished MESL, prior to placement of the upper membrane (Fig. 10).

The membranes were approximately $3 \mathrm{~m}(10 \mathrm{ft})$ long and $6.1 \mathrm{~m}(20 \mathrm{ft})$ wide. Each membrane was overlapped $305 \mathrm{~mm}(1 \mathrm{ft})$ when seamed. Two types of tape were alternately used to seal the seams. There were 21 different test sections consisting of six different membranes and various quantities of membrane protection. Some of the test sections had no membrane protection while others had up to three layers of geotextile protection (Table 1). Figure 11 shows the completed test section before the gravel was placed on top.

Normally, vehicles should not be allowed to drive on the geotextile while placing the gravel. This was not possible in this case because dump trucks were not available during test section construction. Instead, pans were used to place the gravel and a grader was used to spread the gravel (Fig. 12 and 13). Six inches of gravel was placed on the test section. The gravel used was 100\% crushed stone with angular shape and 51-mm 
Figure 12. Pan placing gravel on the test section.
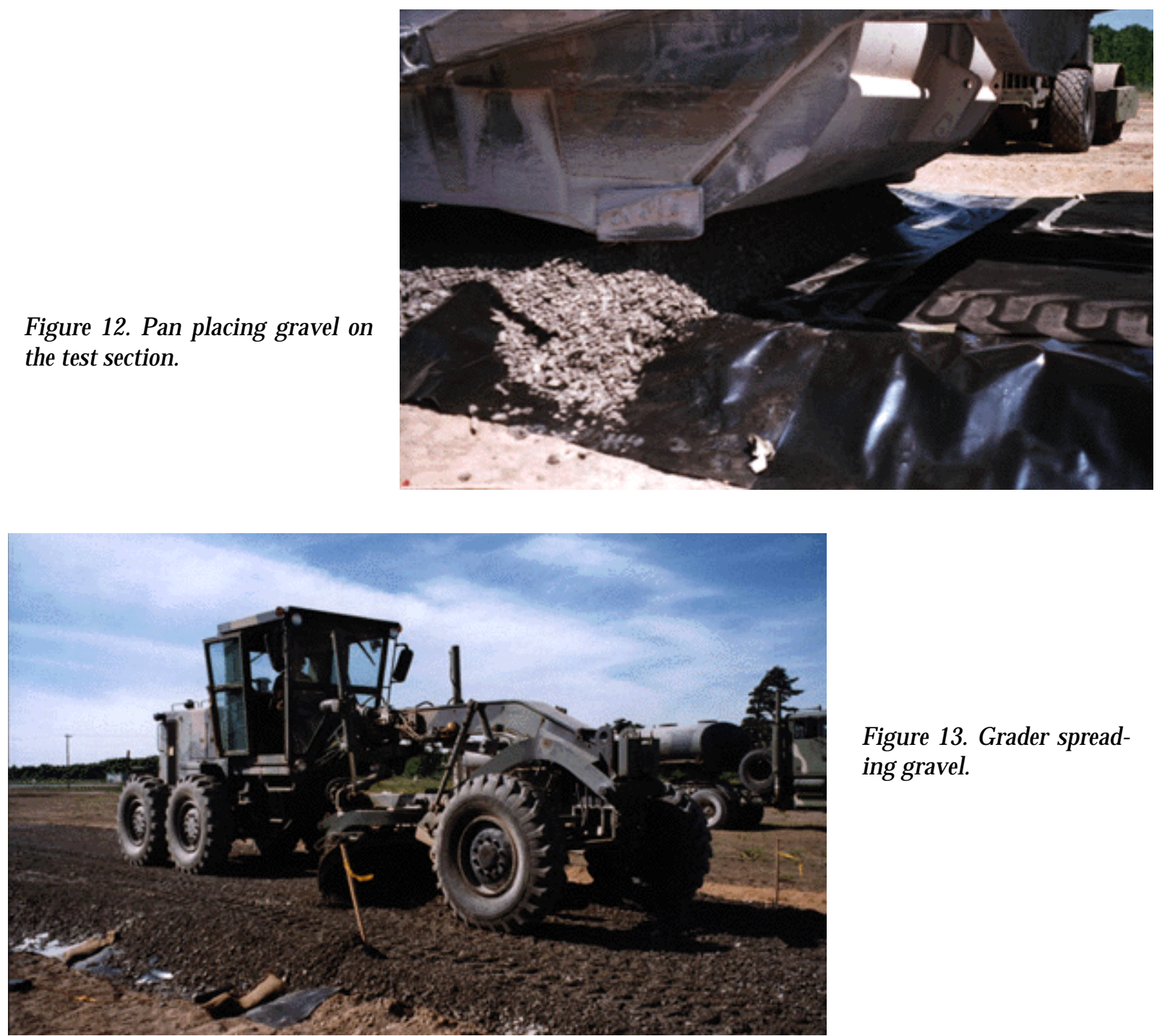

Figure 13. Grader spreading gravel.

Figure 14. Trafficking the puncture test.

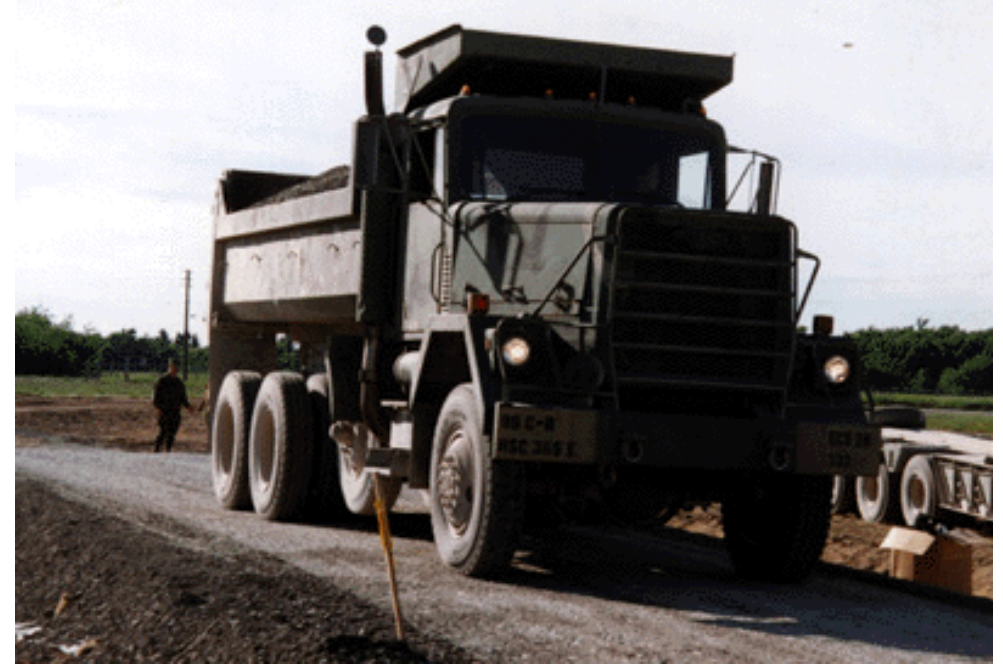

(2-in.) maximum particle size. The gravel was compacted by trafficking with the 20-ton dump truck.

The test section was trafficked with a loaded 20-ton dump truck for 170 passes (Fig. 14). The truck made a loop to traffic and traveled at approximately $10 \mathrm{mph}$ on the test section. The truck also followed approximately the same path each time, simulating a worst-case scenario.

After trafficking, the gravel was removed to observe any membrane damage. A grader removed the top few inches of gravel from the test section. The Fort Drum Fire Department then used one of its fire trucks to remove the rest (Fig. 15 and 16). This procedure worked well and mini- 


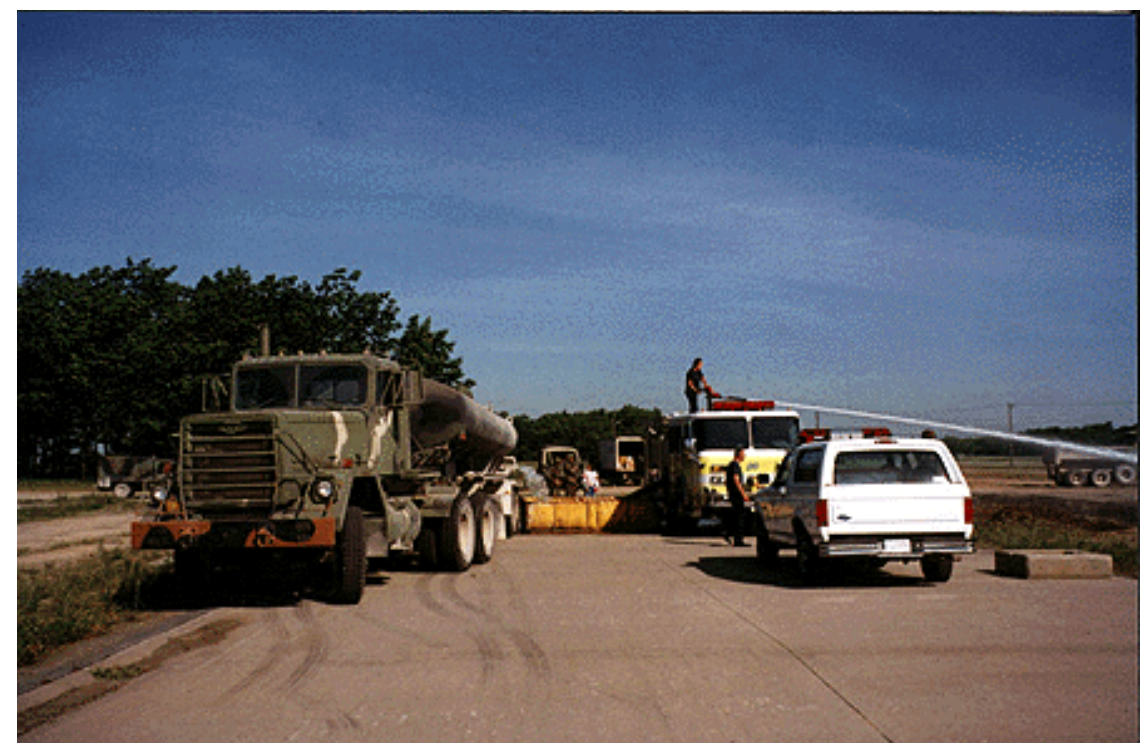

Figure 15. Equipment used to wash gravel off the test section.

Figure 16. Washing gravel.

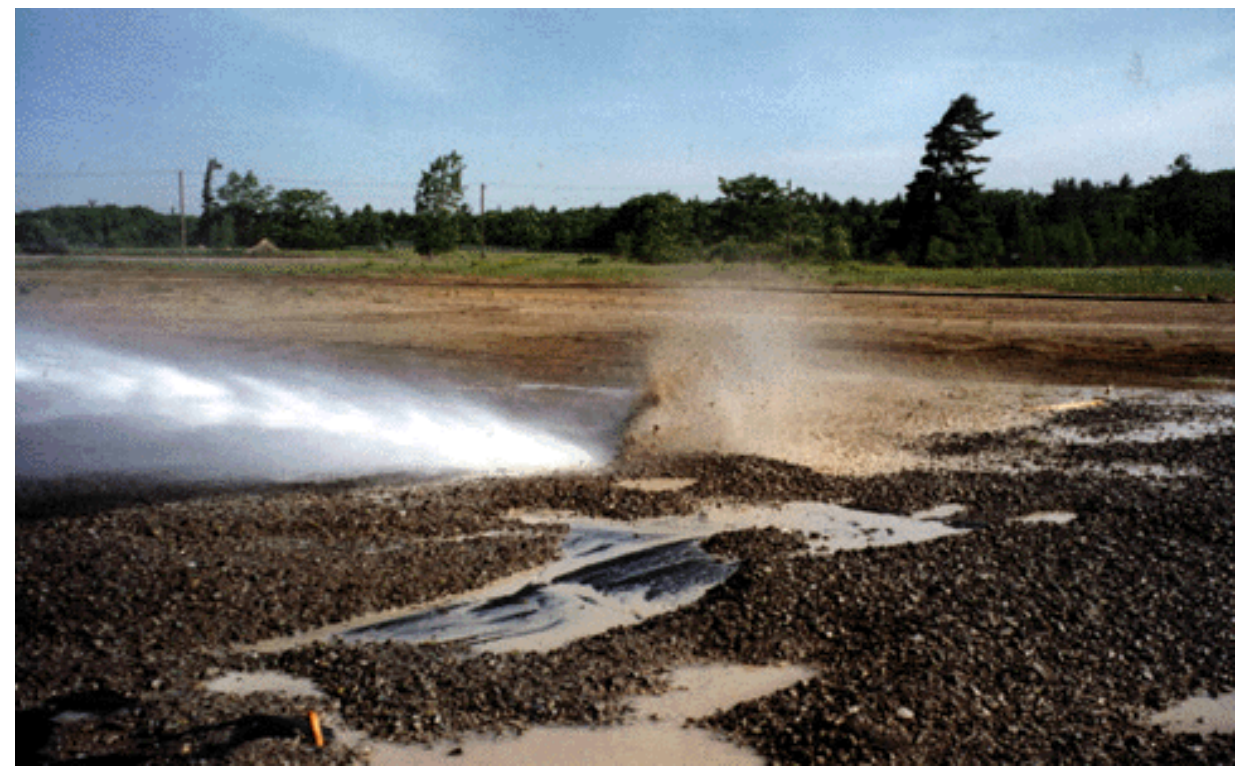

mized damage to the membrane. The membranes were then visually inspected for damage and punctures.

\section{Absorbent demonstration}

The original plans included constructing an additional MESL with a dirty sand/gravel as the fill soil at the Ethan Allen Firing Range (EAFR) in Jericho, Vermont. The plans were changed when it was determined that MESLs could not be constructed by the 365th Combat Heavy Engineering Battalion during the Fort Drum demonstration because of the limited amount of time the engineers were available at EAFR. The new plan was to test the absorbent in a wet soil and qualitatively evaluate its performance.

The absorbent test was conducted at EAFR on
10 August 1997. The 131st Engineering Unit of the Vermont National Guard did the construction.

The test site was an old gravel pit. Because of the low quality of the gravel (due to a high fines content), it was typically used as a fill material at least $0.61 \mathrm{~m}(2 \mathrm{ft})$ below the road surface. A thin organic layer had formed on the gravel and supported grass growth. A test section approximately $4.57 \mathrm{~m}(15 \mathrm{ft})$ wide by $130 \mathrm{~m}(100 \mathrm{ft})$ long was prepared for the test. The existing material was mixed together using a dozer, and additional silty sand was added. Water was added to make the soil muddy (Fig. 17). The wet layer was approximately $305 \mathrm{~mm}$ (1 ft) deep with a solid layer underneath. When trafficked, a 5-ton truck (Fig. 18) would sink to the hard layer, and in some places the soil was too weak to maintain the wheel ruts (Fig. 19). 


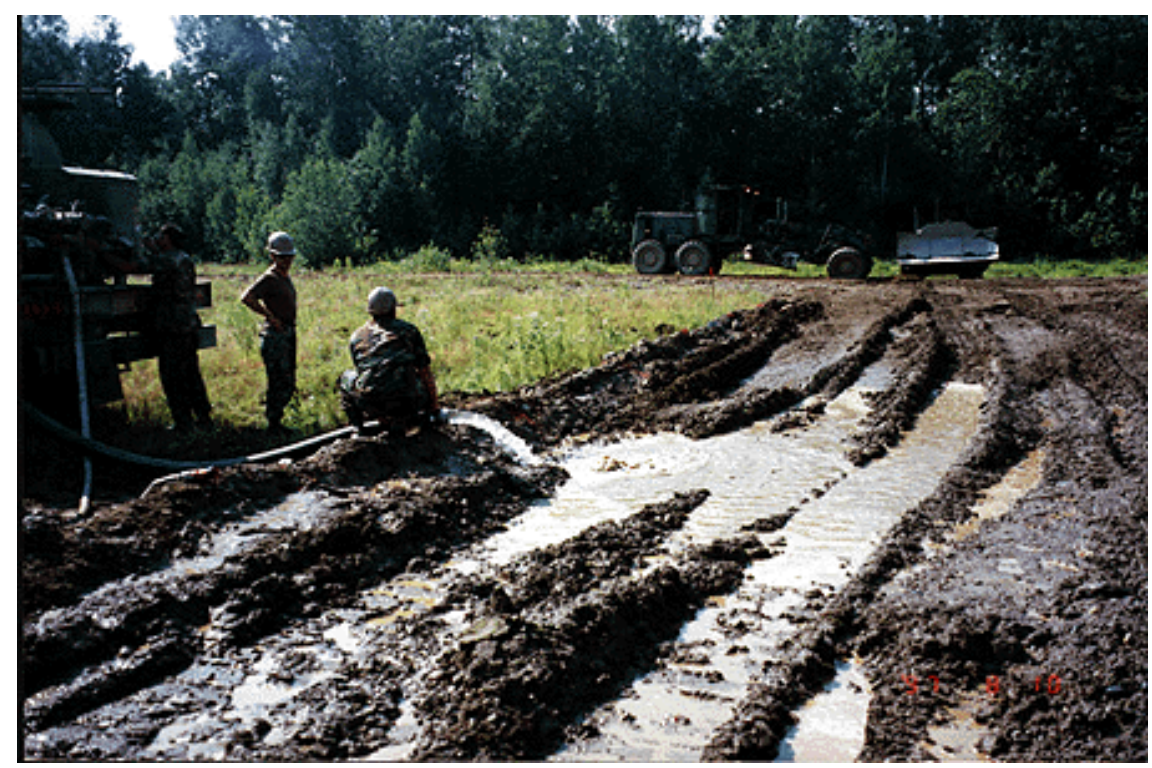

Figure 17. Adding water to the absorbent test section at Ethan Allen Firing Range, Vermont.

Figure 18. Trafficking the absorbent test section.
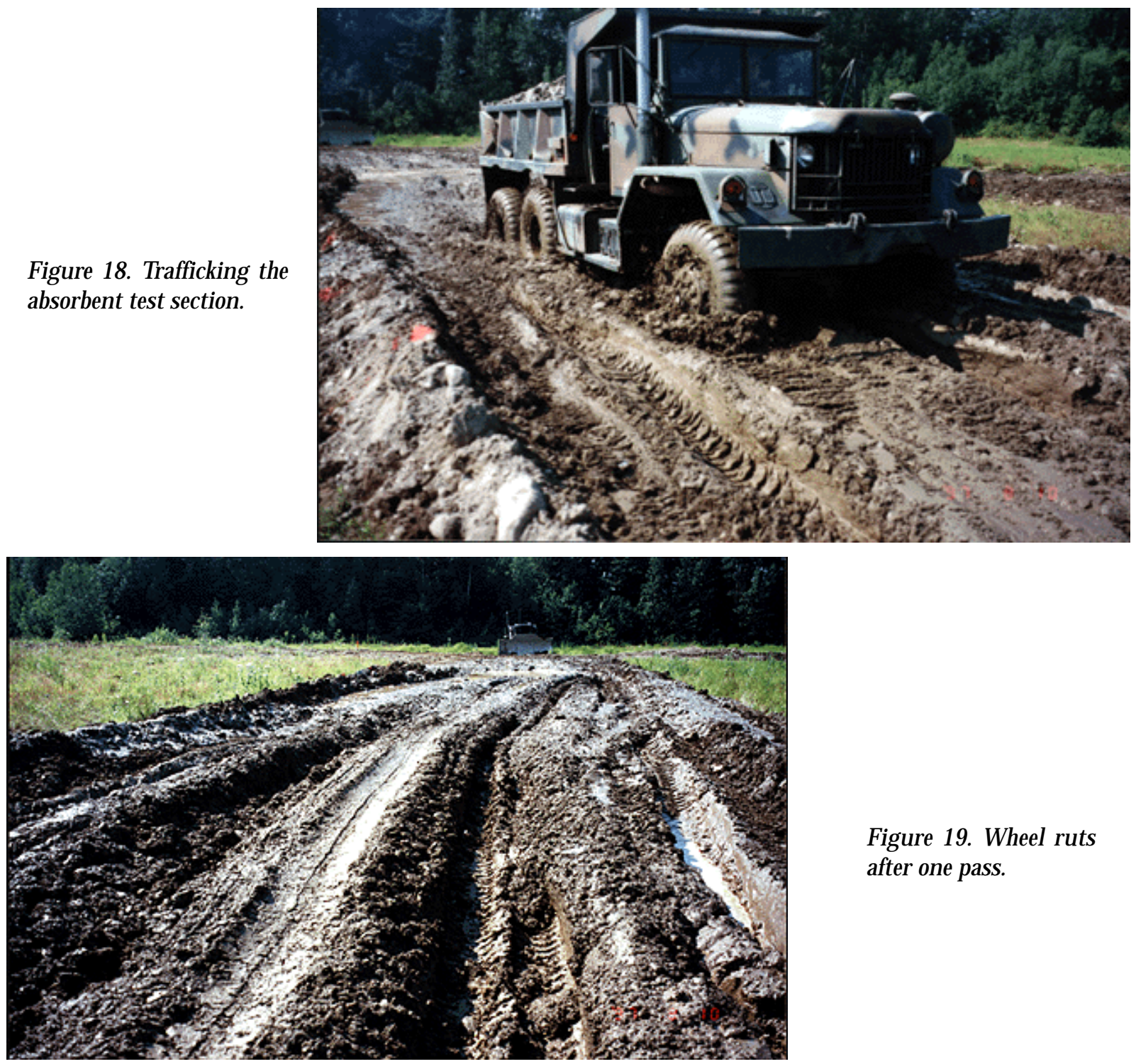

Figure 19. Wheel ruts after one pass. 


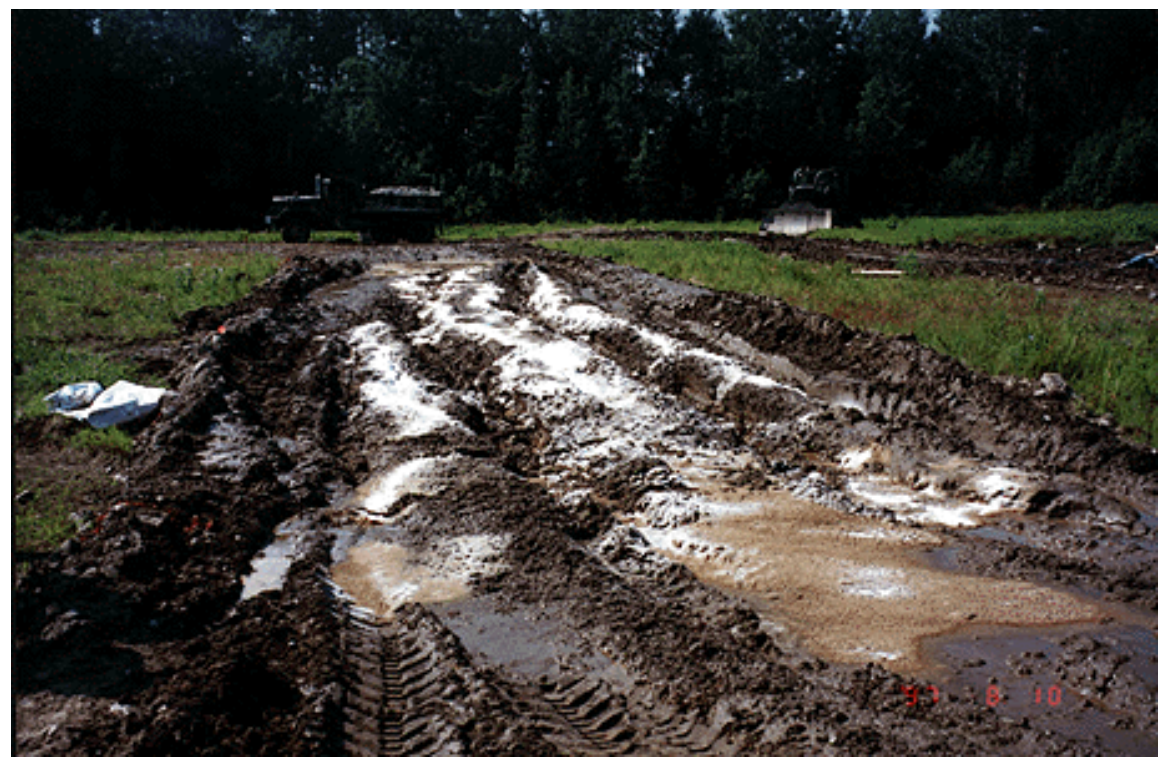

Figure 20. Absorbent spread on test section.

Figure 21. Mixing absorbent and soil together.
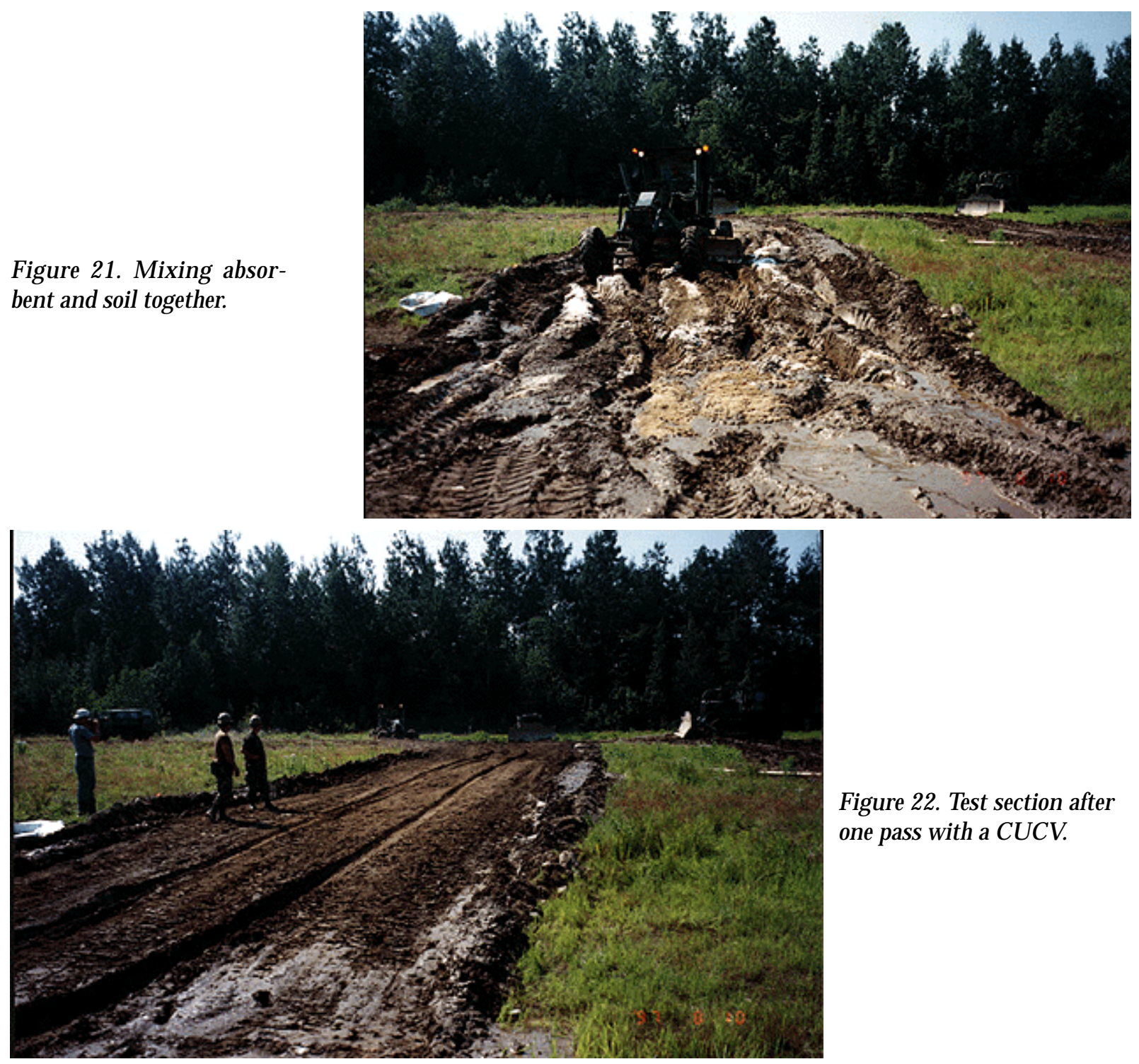

Figure 22. Test section after one pass with a CUCV. 
Next, $136 \mathrm{~kg}(300 \mathrm{lb})$ of the absorbent was added (Fig. 20) and mixed with a grader (Fig. 21). The grader trafficked only the test section and did not use its blade or scarifying teeth to mix the soil and absorbent. After mixing, a dozer was used to back-blade the test section and provide a smooth surface. The center of the section was dryer than the ends. This was due to standing water before the absorbent was added at the far end of the test section and not enough absorbent being added to the near end of the test section.

A Commercial Utility and Cargo Vehicle (CUCV) was driven across the test section leaving approximately 51-mm- (2-in.-) deep ruts in the center of the section and 152-mm (6-in.) ruts on either end (Fig. 22). The CUCV was able to drive through the test section in 2-wheel drive when the test section would have been impassable in 4 -wheel drive before treatment. A loaded 5-ton dump truck was then driven through the test section (Fig. 23 and 24). It left approximately 102mm- (4-in.-) deep ruts in the center and 203-mm(8-in.-) deep ruts on either end. The 5-ton dump truck then trafficked the section 30 times and left 178- to 279-mm- (7- to 11-in.-) deep ruts in the center and far end and 356-mm- (14-in.-) deep ruts at the near end (Fig. 25). The rutting was not caused by the soil being too "wet" but the result of a lack of cohesion. At the end of the test the soil looked dry and friable. The average water content of the top $76 \mathrm{~mm}$ (3 in.) of soil was $17.8 \%$. Its grain size distribution was not determined. The cone penetrometer test results were not valid because the cone hit the larger gravel pieces.

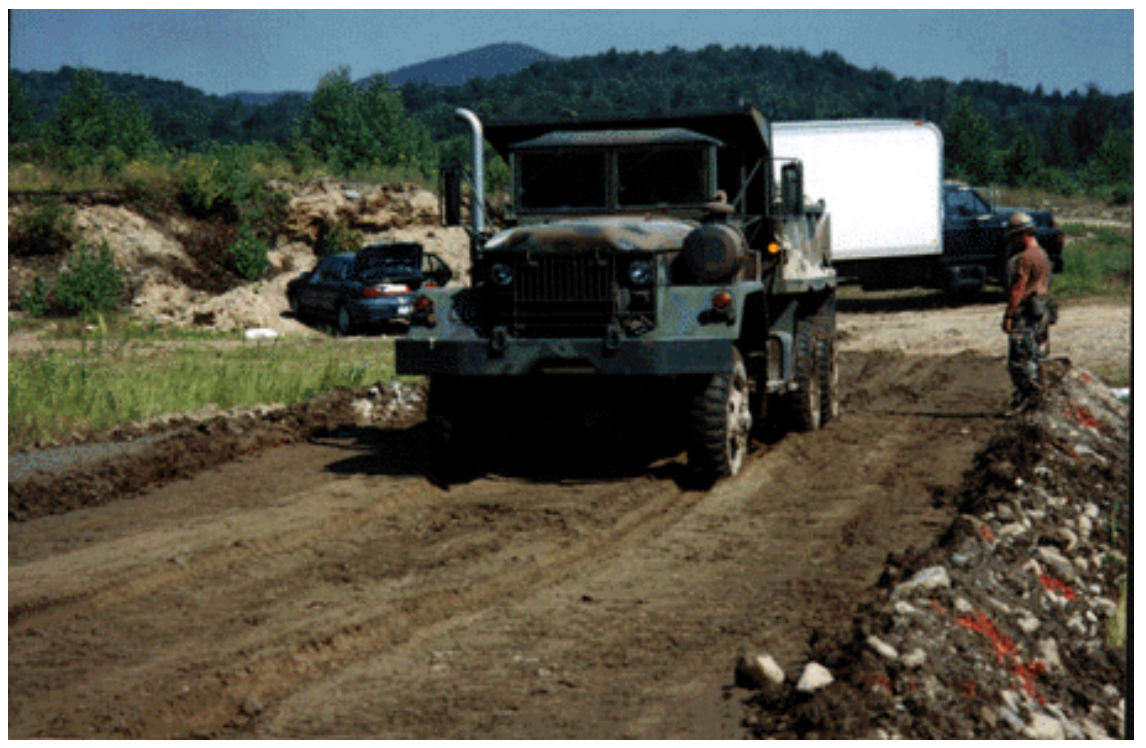

Figure 23. Trafficking the section with a 5-ton dump truck.

Figure 24. Test section after one pass with a 5-ton dump truck.

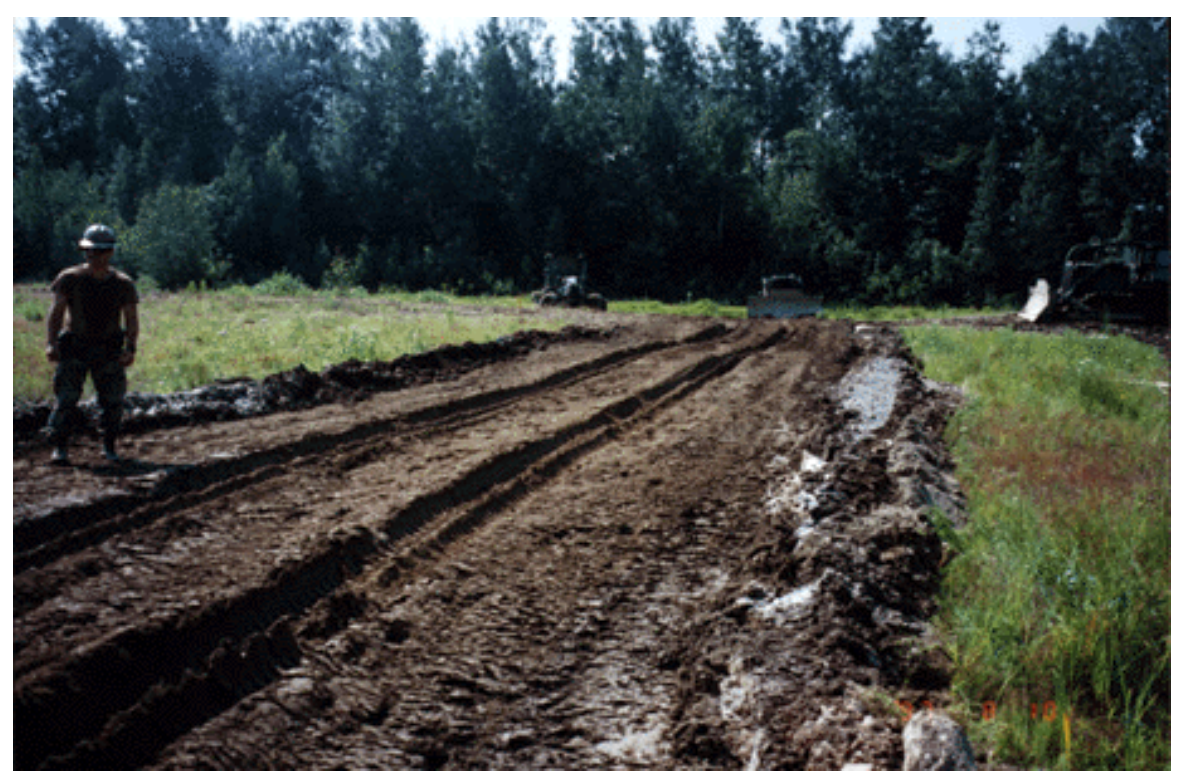




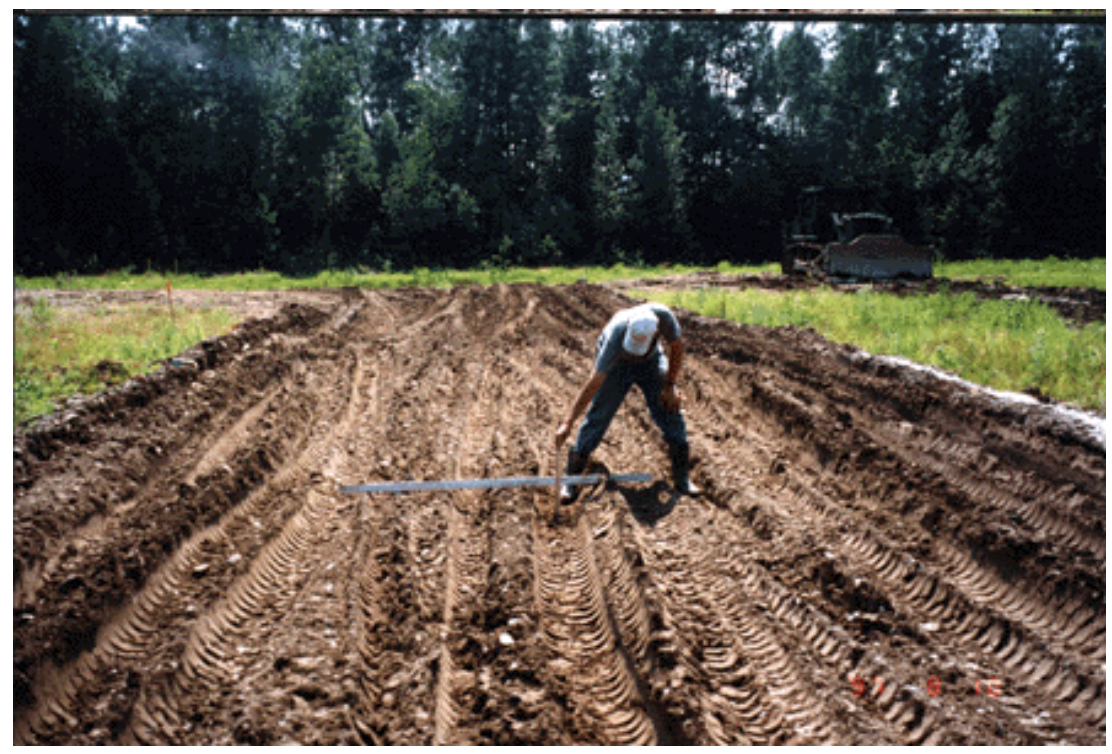

Figure 25. Test section after 30 passes with a 5-ton dump truck.

\section{OBSERVATIONS}

Following are observations that were made during the project. Many minor problems compounded one another. Some of these could be solved by using different equipment or more skilled operators. Other problems, including the weather, the type of native soil available, and membrane folds, are difficult or impossible to control in the field.

\section{MESL demonstration observations}

These observations are from the construction of the MESL and the puncture test. Both had numerous problems that primarily involved equipment availability and operation.

\section{MESL test}

The MESL test was much more time-consuming than planned. It was originally scheduled to be finished in three to four days and took nine days. Most of the delays were due to the lack of equipment and operators.

Weather. The weather is critical to the success of the project. Construction cannot take place during rainy periods. Rain could also turn the excavated, unfinished MESL into a large pool. Wind is also a factor. It can make placing the membranes difficult. If the area is very dry, the construction process can generate a large amount of dust, making the membranes dusty.

Excavation of native soil. Excavating the native soil can be done with a variety of equipment. During the demonstration project the troops were limited to pans and a D-7 dozer. This made excavating the soil and providing smooth surfaces difficult. Not providing a smooth bottom surface will increase the likelihood of the membrane being punctured.

Membranes. The membranes performed well overall with a few minor difficulties. They quickly became covered with a fine film of dust that had to be removed before the tape was applied. Water or rubbing alcohol effectively removed the dust. It was important to replace the wiping towel as soon as it became dirty.

The membranes come folded from the manufacturer. As the thickness increases, the folds take longer to flatten. This would also be affected by temperature, with colder temperatures increasing the time. The membranes also were factoryseamed to form larger sheets. Sealing across the seams could be difficult and a source of potential leaks.

Placing membranes. The membranes were easy to place when there was no wind, but because they are very large, a strong wind can make it difficult or impossible to place them (Fig. 26). The membranes also needed to be held down if the wind increased after they were placed.

Several troops were required to place the membranes. As the size increased, the number of troops required also increased. Four to six troops worked well for the membranes $(10.7 \times 36.6 \mathrm{~m}[35 \mathrm{ft} \times 120$ $\mathrm{ft}]$ ) used in this project.

Tape. The tapes worked very well. Fab tape was preferred because it was easier to use. It is more robust, has more tension strength, is not blown around by the wind as easily, and can be adjusted 
Figure 26. Placing top membrane during light winds.

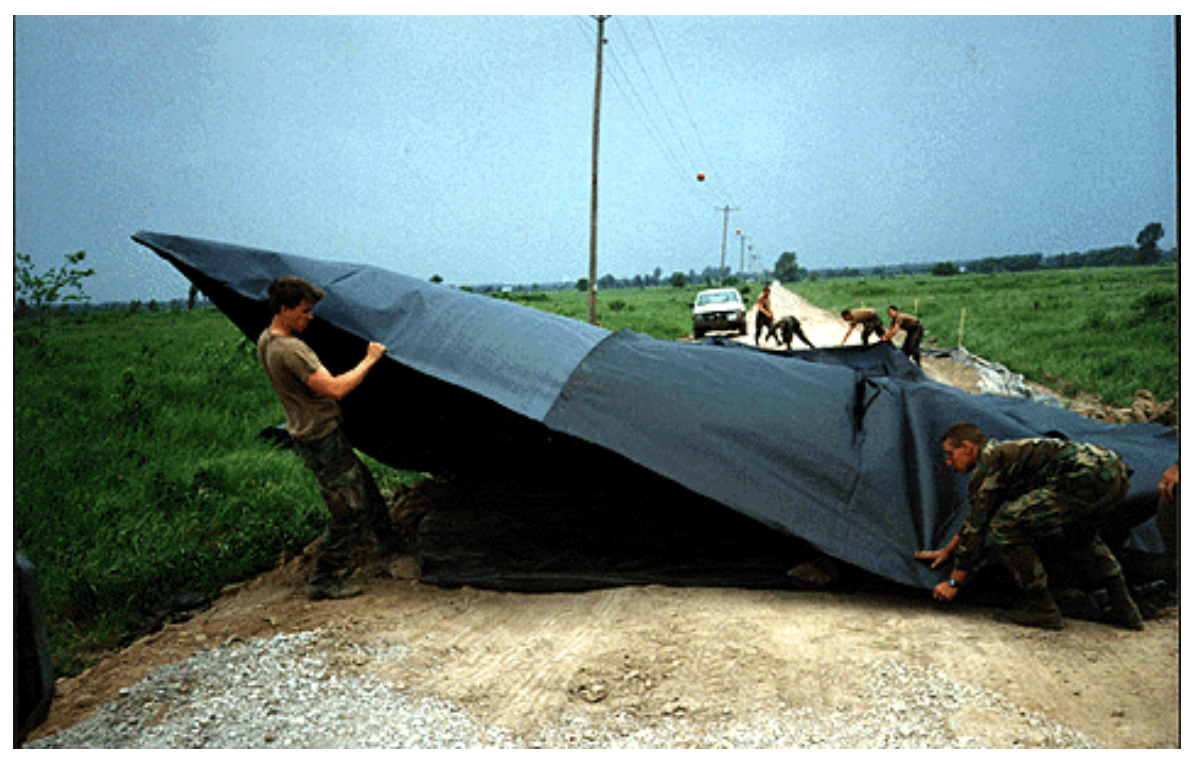

after it is placed on the membrane. The Poly Seal tape is permanently adhered to the plastic as soon as it touches it.

It is recommended that both tapes be kept above $10^{\circ} \mathrm{C}\left(50^{\circ} \mathrm{F}\right)$ before use, e.g., by keeping the tape in a heated vehicle. It is also possible to heat the tape and the membrane with a heat gun as the tape is being applied. (As mentioned in the "Membrane sealing" section, using a heat gun would require a generator.)

Placing, compacting, and grading the encapsulated soil. This is one of the most difficult steps. The initial lift must be placed carefully to avoid damaging the lower membrane. Care must also be taken when spreading and compacting near the sides of the membranes. The membrane can be torn easily by the heavy equipment (Fig. 27).
Cutting the final grade or removing any excess soil from the edge near the membrane requires great care. It may be necessary to use brooms or shovels to remove excess soil.

It is critical that the top surface be smooth with no loose material. Because the upper membrane is not protected from the fill material and small stones, hard soil particles, etc., can easily puncture the membrane. Small stones may be tracked on the surface by vehicle tires, shoes, etc.

Sealing membranes. The membranes must be clean for the tape to bond properly. Dust quickly accumulates on the membranes. If the soil becomes wet at any time the membranes may become muddied and then must be cleaned. The membranes can be cleaned with water and, if required, rubbing alcohol.

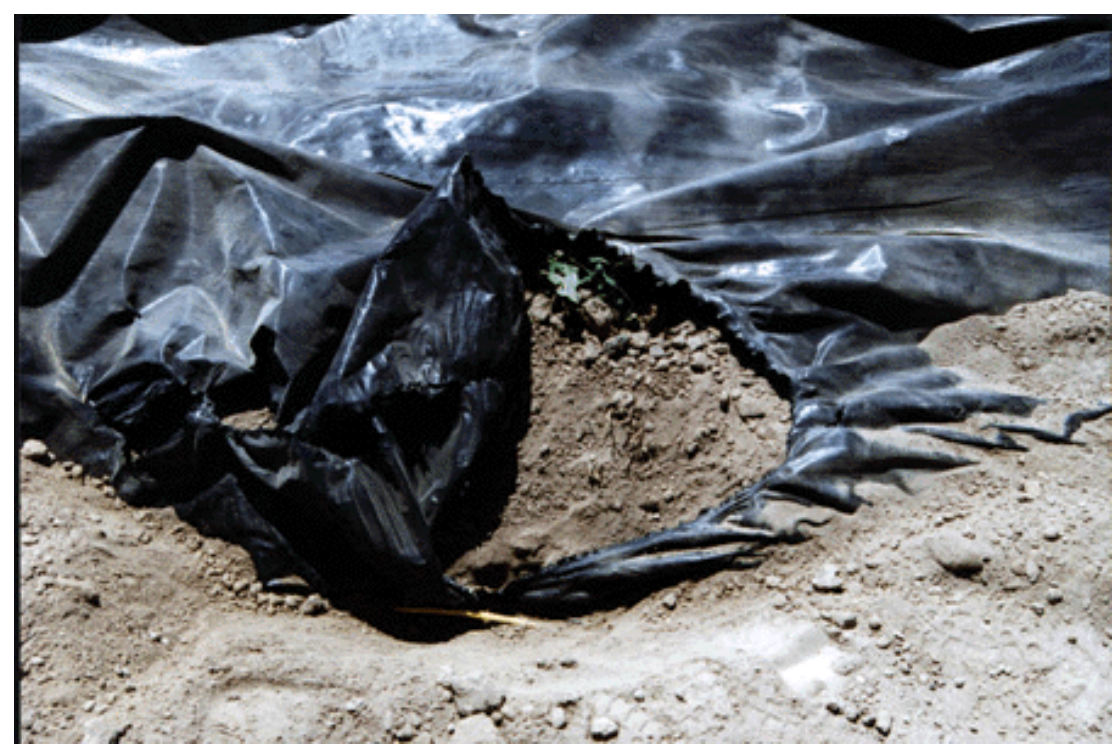

Figure 27. Membrane tear. 
The most difficult part of sealing the membranes is caused by the folds or creases in the membranes. The bottom membrane had numerous folds caused by the irregular excavation. The top membrane had a few larger folds caused by the irregular soil surface.

It may be necessary to walk on the membranes when sealing them. Care needs to be taken not to puncture the membranes when doing so. Stones caught in shoe treads can easily puncture the membrane. Hard-soled shoes also can cause problems.

MESL ends. The MESL ends are the most complicated part of the construction. The bottom membrane needs to be protected as the MESL is filled. Vehicles carrying fill soil need to travel over the bottom membrane at the MESL ends. Geotextiles and plywood are possible methods of protection, but must be removed when the fill soil is in place so the membranes can be sealed.

When the membranes are sealed, the side of the bottom membrane needs to be sealed to the end of the bottom membrane. The top membrane is then sealed to the bottom membrane. The exact sealing order and method will change from site to site and needs to be determined in the field.

Placing the geotextile. Placing the geotextile was easy and went quickly. Troops should walk on the geotextile and not the membrane. Care must be taken when walking on the geotextile because it will slide on some membranes.

Placing the wearing course. A 152-mm (6-in.) gravel wearing course was used. It was difficult to place a uniform thickness of gravel because the surface of the MESL was not level. Care is still needed when spreading the gravel. A bucket loader caught the top of the MESL when spreading the gravel (Fig. 28).

Figure 28. Top-membrane tear, caused by a bucket loader.
Lime mixing. Mixing the lime and the clay soil went well. The lime was mixed into the top 102 $\mathrm{mm}$ (4 in.) of soil. Mixing to greater depths would have been difficult. Maintaining a uniform moisture content is important. Removing the mixed soil for trucking to the MESL site was challenging. At times too much soil was removed and untreated clay was added to the clay-lime mixture.

\section{Puncture test}

It is critical that the upper membrane not be punctured during construction or trafficking. Even one puncture can lead to localized failure of the MESL. If the failure is not corrected immediately, its size can increase rapidly. Traffic and wet weather will speed the rate of failure. Therefore, one puncture was considered failure. The number of punctures was not quantified. Visual observations were taken mostly along the wheel paths.

The results are divided by the amount of protection used. The Permalon Ply X-210G (composite membrane) was analyzed separately because it has some protection without a separate geotextile.

No protection. Two membranes without protection had the following test results.

- RUFCO 2010B. The membrane had numerous puncture holes ranging from 12 to $50 \mathrm{~mm}(0.5$ to 2 in.), depressions, scratches, and stretch marks.

- Permalon Ply X-210. There were numerous holes and many depression marks on the membrane.

One-layer geotextile.

- RUFCO 1010B. There were many continuous scratches on the wheel path, long stretch

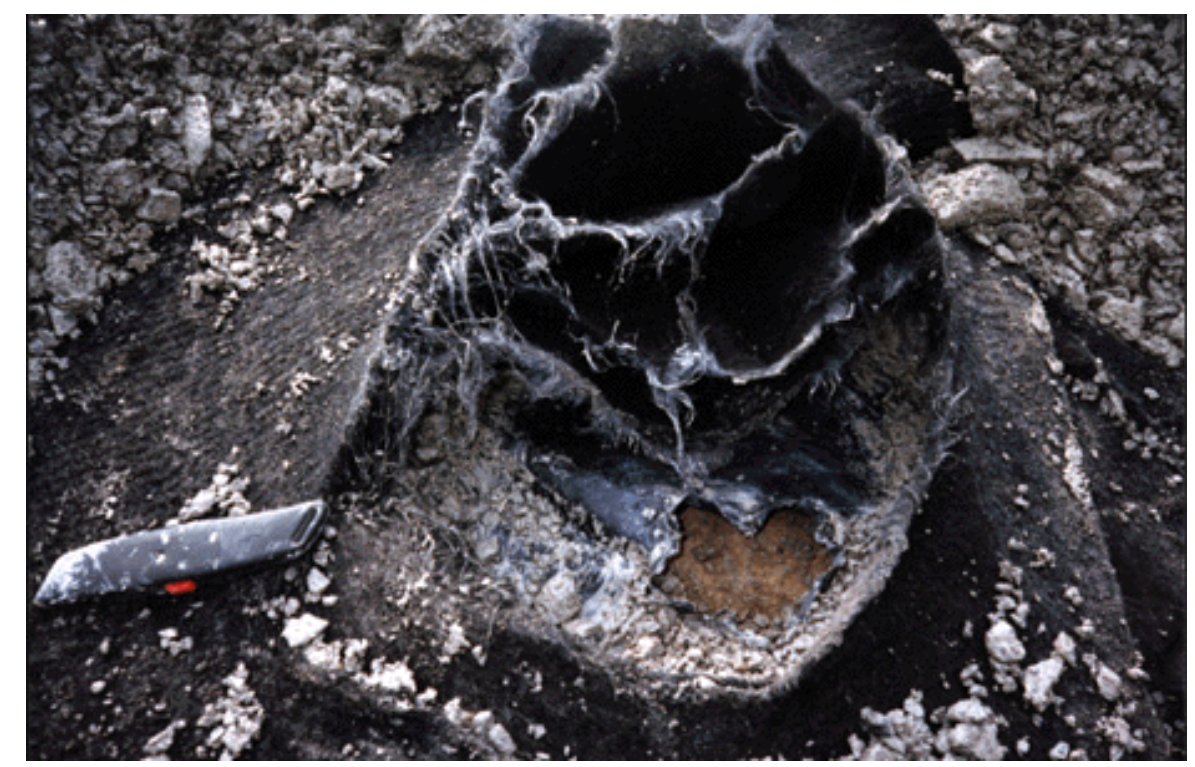


marks, depressions, and puncture holes ranging from 3 to $10 \mathrm{~mm}$ (0.12 to $0.40 \mathrm{in}$.) in diameter.

- RUFCO 2010B. There were 1.2- to 1.8-m (4- to 6-ft) straight scratches on the wheel path, a few holes ranging from 2 to $5 \mathrm{~mm}$ (0.08 to 0.2 in.), and a few depressions.

- RUFCO 3010B. There were a few 5- to 10-mm (0.2- to 0.4-in.) puncture holes, some depression marks, and scratch lines ranging from 75 to $200 \mathrm{~mm}$ ( 3 to $8 \mathrm{in}$.) in length and 2 to $10 \mathrm{~mm}$ ( 0.08 to 0.4 in.) in width on the wheel path.

- DURA-SKRIM 12 BBR. There were some depressions, some tiny puncture holes, and some scratches about 75 to $200 \mathrm{~mm}$ ( 3 to $8 \mathrm{in}$.) long and 2 to $5 \mathrm{~mm}$ (0.08 to $0.2 \mathrm{in}$.) wide on the wheel path.

- Permalon Ply X-210. There were plenty of scratch lines on the membrane ranging from 150 to $250 \mathrm{~mm}$ ( 6 to $10 \mathrm{in}$.) long and 5 to $12 \mathrm{~mm}$ (0.2 to 0.5 in.) wide; these scratch lines had puncture holes.

Two-layer geotextile.

- RUFCO 1010B. There were some holes ranging from 5 to $10 \mathrm{~mm}$ (0.2 to $0.4 \mathrm{in}$.); these were not restricted to the wheel path. There were scratch lines and a few depressions.

- RUFCO 2010B. On the wheel path, there were 100- to 200-mm- (4- to 8-in.-) long scratch lines, some of which had 2- to 10-mm (0.08- to 0.4 -in.) puncture holes and a few depressions. Other areas of the membrane had no holes and no stretch marks.

- RUFCO 3010B. This membrane looked nearly new with minimal scratches about 80 to 180 $\mathrm{mm}$ (3 to $7 \mathrm{in}$.) long and about 5 to $10 \mathrm{~mm}(0.2$ to 0.4 in.) wide on the wheel path. These scratch marks did not have noticeable holes and there were no depressions on the membrane.

- DURA-SKRIM 12 BBR. The membrane had a few 2- to 5-mm (0.08- to 0.2-in.) puncture holes and minimal scratches.

- Permalon Ply X-210. The membrane looked good in most areas except for a few needlesize (0.25- to 1 -mm [0.01- to 0.04-in.]) puncture holes and a few scratches ranging from 3 to 4 $\mathrm{mm}(0.12$ to 0.16 in.) in width, 100 to $200 \mathrm{~mm}$ (4 to 8 in.) in length.

Three-layer geotextile.

- RUFCO 2010B. The membrane looked as good as new, with minimal scratches, no noticeable depressions, and no puncture holes.

- DURA-SKRIM 12 BBR. There were a few barely obvious scratches, very few needle-size puncture holes, and no depressions on the membrane.

Composite membrane. The Permalon Ply X210G was tested with no additional protection and with one and two layers of geotextile for protection. It was more difficult to visually determine if this membrane was punctured. The geotextile on the membrane with no additional protection was rough and the geotextile was not uniform. This was probably caused by water when the gravel was washed from the surface. Although no holes were visible, additional protection is recommended. The membrane with one and two layers of protection performed well with no noticeable holes.

Seam sealing. The seams were intact and showed no signs of leakage. It was not possible to successfully seam the two sections of composite membrane together because one side had the geotextile on it. This prevented a direct seal with the polyethylene membrane.

\section{Absorbent demonstration observations}

The absorbent was very effective at "drying" the dirty sand/gravel soil. Before treatment the test section was impassable for small 4-wheeldrive vehicles and extremely difficult to walk across. The absorbent made the section passable to small 4-wheel-drive vehicles and walking across the section was very easy after treatment.

The section still rutted too much during truck traffic for use in a MESL. A 152-mm (6-in.) wearing course would reduce rutting but would not eliminate it. Rutting would stress the upper membrane and could lead to punctures and tearing.

\section{CONCLUSIONS}

\section{Materials and construction}

The materials proposed for the new construction method performed well. The geotextile protected the membranes effectively in the puncture test when three layers were used. The tapes were generally easy to apply and formed watertight seams. However, the tapes would be more difficult to use in cold weather.

The construction procedures are too exacting to be realistically constructed in the field, especially expediently. It is too easy to have the bottom membrane torn when compacting or finish-grading the fill material. The ends of the MESL are also very difficult to construct. The troops also voiced concern over having to back up their dump trucks to dump gravel on the geotextile. 


\section{Absorbent test}

The absorbent provides an excellent way to "dry" silty gravelly sands and possibly silts. It works extremely well for light traffic and foot traffic. However, soils became friable and rutted under repeated truck traffic. The absorbents will not provide enough strength for these soils to be used inside a MESL.

\section{RECOMMENDATIONS}

The use of MESLs is not recommended for Army engineer construction. The construction procedure is not suitable for construction of lines of communication (LOC) in the theater of operations. If a unit does feel that a MESL is an appropriate project, Appendix A recommends materials for constructing one.

Absorbents will not work for drying the encapsulated soil for a MESL. However, the absorbents worked extremely well for foot traffic and light vehicular traffic and moderately well for truck traffic when not used in conjunction with a MESL.

\section{LITERATURE CITED}

Asphalt Institute (Undated) Asphalt Emulsion: A Basic Asphalt Emulsion Manual. Manual Series No. 19, Third Edition, Asphalt Institute, Asphalt Emulsion Manufacturers Association.

Eaton, R.A., and R.L. Berg (1980) New Hampshire field studies of membrane encapsulated soil layers with additives. U.S. Army Cold Regions Research and Engineering Laboratory, Special Report 80-33.

Joseph, A.H., and S.L. Webster (1971) Techniques for rapid road construction using membraneenveloped soil layers. U.S. Army Waterways Experiment Station, Instruction Report S-71-1.

Joseph, A.H., R.D. Jackson, and S.L. Webster (1973) Rapid road construction using membraneenveloped soil layers. U.S. Army Waterways Experiment Station, Miscellaneous Paper S-73-5.

Koerner, R.M., R.F. Wilson-Fahmy, and D. Narejo (1996) Puncture protection of geomembranes. Part III: Examples. Geosynthetics International, 3(5): 655-671.

Narejo, D., R.M. Koerner, and R.F. Wilson-Fahmy (1996) Puncture protection of geomembranes. Part II: Experimental. Geosynthetics International, 3(5): 629-653.

Raven Industries (Undated a) Accessories. Flexible Films Department, Raven Industries, Sioux Falls, South Dakota.
Raven Industries (Undated b) DURA-SKRIM. Flexible Films Department, Raven Industries, Sioux Falls, South Dakota.

Raven Industries (Undated c) RUFCO 2010B \& 3010B. Flexible Films Department, Raven Industries, Sioux Falls, South Dakota.

Raven Industries (Undated d) RUFCO 610B \& 1010B. Flexible Films Department, Raven Industries, Sioux Falls, South Dakota.

Reef Industries, Inc. (1996a) Fab Tape Sales Specifications. Reef Industries, Inc., Houston, Texas.

Reef Industries, Inc. (1996b) Permalon Ply X-150. Reef Industries, Inc., Houston, Texas.

Reef Industries, Inc. (1996c) Permalon Ply X-210. Reef Industries, Inc., Houston, Texas.

Reef Industries, Inc. (1996d) Permalon Ply X-210G. Reef Industries, Inc., Houston, Texas.

Richardson, G.N. (1996) Field evaluation of geosynthetic protection cushions. Geotechnical Fabrics Report, March 1996, p. 20-25.

Sale, J.P., F. Parker Jr., and W.R. Barker (1973) Membrane encapsulated soil layers. Journal of the Soil Mechanics and Foundations Division, Proceedings of the American Society of Civil Engineers, 99(SM12): 1077-1089.

Schaefer, D. (1973) MESL road construction at Fort Wainwright, Alaska. USA Cold Regions Research and Engineering Laboratory, Technical Note (unpublished).

Smith, N. (1978) Techniques for using MESL (membrane encapsulated soil layers) in roads and airfields in cold regions. In Proceedings of the Conference on Applied Techniques for Cold Environments, ASCE, May, p. 560-570.

Smith, N. (1979) Construction and performance of membrane encapsulated soil layers in Alaska. USA Cold Regions Research and Engineering Laboratory, CRREL Report 79-16.

Smith, N., and J. Karalius (1973) Construction of a MESL road test section at Elmendorf Air Force Base, Anchorage, Alaska. USA Cold Regions Research and Engineering Laboratory, Technical Note (unpublished).

Stockhausen, Inc. (1997) Material Safety Data Sheet (MSDS) for AP 88, Stockhausen, Inc., Greensboro, North Carolina.

Webster, S.L. (1974a) Construction of MESL demonstration road at Fort Hood, Texas, May 1972. USA Waterways Experiment Station, Miscellaneous Paper S-74-13.

Webster, S.L. (1974b) Implementation package 74-2: Users Manual for Membrane Encapsulated Pavement Sections (MEPS). USA Waterways Experiment Station. Prepared for Implementation Division, Office of Development, Federal 
Highway Administration, U.S. Department of Transportation, Washington, D.C.

Webster, S.L. (1996) Construction with geotextiles. USA Waterways Experiment Station, Internal Report (unpublished).

Webster, S.L., and R.A. Andress (1976) Investiga- tion of fabrics and bituminous surfaces for use in MESL construction. USA Waterways Experiment Station, Miscellaneous Paper S-76-14.

Wilson-Fahmy, R.F., and R.M. Koerner (1996) Puncture protection of geomembranes. Part I: Theory. Geosynthetics International, 3(5): 605-628. 


\section{APPENDIX A: RECOMMENDED MATERIALS FOR CONSTRUCTING A MESL}

\section{GENERAL INFORMATION}

Construction of a MESL with the following materials requires care and good planning. Placing the membranes should not be attempted in windy weather because they can act as large sails and become extremely difficult or even impossible to hold down.

The top layer of the fill soil should not contain any sharp soil particles or rocks that can puncture the membrane from below. All seams should be placed so water drains away from them and does not pond on or near them. Extreme care must be taken when placing the gravel for the wearing surface.

Traffic should be controlled on the sections. No hard starting, stopping, or turning should be allowed.

\section{RECOMMENDED MATERIALS}

\section{Bottom membrane}

The bottom membrane should be at least 0.152 mm (6 mil) thick. A quality membrane (such as Raven's RUFCO 610) should be used. The mem- branes or plastic sheets sold in hardware stores are not of acceptable quality. If the subgrade soil has sharp rocks, a slightly thicker membrane, such as Reef's Ply X-150, should be used.

\section{Top membrane}

The top membrane should be at least $0.51 \mathrm{~mm}$ (20 mil) thick, such as Raven's RUFCO 2010 or Reef's Ply X-210.

\section{Geotextile}

Three layers of a $271-\mathrm{g} / \mathrm{m}^{2}\left(8-\mathrm{oz} / \mathrm{yd}^{2}\right)$ nonwoven geotextile should be used. If the gravel is extremely angular, if the traffic volume will be very high, or if the gravel cover is less than $152 \mathrm{~mm}$ (6 in.), four layers of geotextile should be used. If the gravel is rounded and the design life is short, it may be possible to use only two layers.

\section{Tape}

A heavy tape that is forgiving and that works well in windy conditions (for example, Fab tape) is easiest to work with. 


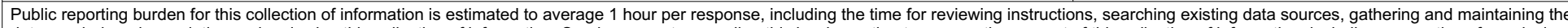

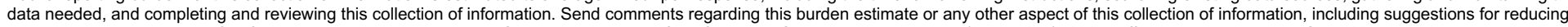

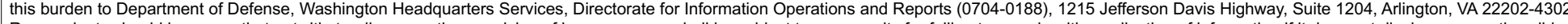

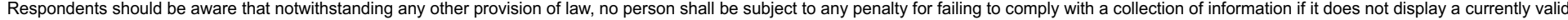
OMB control number. PLEASE DO NOT RETURN YOUR FORM TO THE ABOVE ADDRESS.
1. REPORT DATE (DD-MM-YY)
2. REPORT TYPE
3. DATES COVERED (From - To)

July 2000

Technical Report

4. TITLE AND SUBTITLE

5a. CONTRACT NUMBER

Expedient MESL Construction in Cold Weather

5b. GRANT NUMBER

5c. PROGRAM ELEMENT NUMBER

\section{AUTHOR(S)}

5d. PROJECT NUMBER

Jeffrey A. Stark, Rosa T. Affleck, and Sherri A. Orchino

5e. TASK NUMBER

5f. WORK UNIT NUMBER

\section{PERFORMING ORGANIZATION NAME(S) AND ADDRESS(ES)}

\section{PERFORMING ORGANIZATION REPORT} NUMBER

U.S. Army Engineer Research and Development Center

Cold Regions Research and Engineering Laboratory

72 Lyme Road

ERDC/CRREL TR- 00-8

Hanover, New Hampshire 03755-1290

9. SPONSORING/MONITORING AGENCY NAME(S) AND ADDRESS(ES)

10. SPONSOR / MONITOR'S ACRONYM(S)

Office of the Chief of Engineers

Washington, D.C. 20314-1000

11. SPONSOR / MONITOR'S REPORT NUMBER(S)

\section{DISTRIBUTION / AVAILABILITY STATEMENT}

Approved for public release; distribution is unlimited.

Available from NTIS, Springfield, Virginia 22161.

\section{SUPPLEMENTARY NOTES}

\section{ABSTRACT}

A new method of constructing membrane-encapsulated soil layers (MESLs) using plastic membranes, geotextiles, tapes for sealing the membranes, and absorbents for drying the soil was demonstrated. These materials would allow construction of a MESL in cold weather. The demonstration took place at Fort Drum, New York, and at Ethan Allen Firing Range, Jericho, Vermont. Three layers of a $271-\mathrm{g} / \mathrm{m}^{2}\left(8-\mathrm{oz} / \mathrm{yd}^{2}\right)$ geotextile successfully protected the membrane during a puncture test, and absorbents successfully caused the soil to act drier to increase vehicle trafficability. However, the geotextile is still too weak to be used in a MESL. Although the individual components performed well, the construction process is too exacting to be performed successfully and is not recommended for Army engineers.

\section{SUBJECT TERMS}
Absorbent
Frost-susceptible soils
MESL
Thaw weakening
Expedient road construction Membrane-encapsulated soil layer Moisture-susceptible soils

\begin{tabular}{|c|c|c|}
\hline a. REPORT & b. ABSTRACT & c. THIS PAGE \\
\hline $\mathrm{U}$ & $\mathrm{U}$ & $\mathrm{U}$ \\
\hline
\end{tabular}

17. LIMITATION OF OF ABSTRACT

$\mathrm{U}$
18. NUMBER OF PAGES 19a. NAME OF RESPONSIBLE PERSON

19b. TELEPHONE NUMBER (include area code) 